\title{
Systematic Review \\ Promising Epigenetic Biomarkers for the Early Detection of Colorectal Cancer: A Systematic Review
}

\author{
Sorina Andreea Anghel ${ }^{1,2,+}$, Corina-Bianca Ioniță-Mîndrican ${ }^{1,3,+}$, Ioana Luca ${ }^{1, *}$ and Anca Lucia Pop ${ }^{1}$ \\ 1 Department of Clinical Laboratory, Food Safety, "Carol Davila" University of Medicine and Pharmacy, \\ 6 Traian Vuia Street, 020945 Bucharest, Romania; sorina-andreea.anghel@rez.umfcd.ro (S.A.A.); \\ corina-bianca.ionitamindrican@rez.umfcd.ro (C.-B.I.-M.); anca.pop@umfcd.ro (A.L.P.) \\ 2 Department of Molecular Cell Biology, Institute of Biochemistry, Splaiul Independentei 296, \\ 060031 Bucharest, Romania \\ 3 Department of Toxicology, Faculty of Pharmacy, "Carol Davila" University of Medicine and Pharmacy, \\ 020945 Bucharest, Romania \\ * Correspondence: ioana.luca@rez.umfcd.ro; Tel.: +40-773302722 \\ + These authors are equal first authors in this work.
}

Citation: Anghel, S.A.;

Ioniță-Mîndrican, C.-B.; Luca, I.; Pop, A.L. Promising Epigenetic

Biomarkers for the Early Detection of Colorectal Cancer: A Systematic

Review. Cancers 2021, 13, 4965.

https://doi.org/10.3390/

cancers13194965

Academic Editor: Jesús García-Foncillas

Received: 1 August 2021

Accepted: 29 September 2021

Published: 2 October 2021

Publisher's Note: MDPI stays neutral with regard to jurisdictional claims in published maps and institutional affiliations.

Copyright: (c) 2021 by the authors. Licensee MDPI, Basel, Switzerland. This article is an open access article distributed under the terms and conditions of the Creative Commons Attribution (CC BY) license (https:/ / creativecommons.org/licenses/by/ $4.0 /)$.
Simple Summary: High-performance, non-invasive screening is a requirement in colorectal cancer $(\mathrm{CRC})$ as early detection is a key in reducing disease-related mortality in CRC patients. However, colonoscopy, the actual gold standard in CRC screening, is invasive and often avoided by patients. Conventional screening methods encounter several limitations; therefore, new testing strategies have been considered. DNA methylation is the most prevalent epigenetic alteration that occurs in all stages of carcinogenesis. Our research focused on identifying potential DNA methylation single biomarkers or panels as promising tools in the early detection of CRC; it evaluated methylated genes currently targeted by already approved diagnostic kits. A panel of five CTCF methylated binding sites holds the promise for early-stage specific detection of CRC. CRC screening compliance and accuracy can be enhanced by employing a stool mt-DNA methylation test.

Abstract: In CRC, screening compliance is decreased due to the experienced discomfort associated with colonoscopy, although this method is the gold standard in terms of sensitivity and specificity. Promoter DNA methylation (hypomethylation or hypermethylation) has been linked to all CRC stages. Study objectives: to systematically review the current knowledge on approved biomarkers, reveal new potential ones, and inspect tactics that can improve performance. This research was conducted according to the Preferred Reporting Items for Systematic Reviews and Meta-Analyses (PRISMA) guidelines; the risk of bias was evaluated using the revised Quality Assessment of Diagnostic Accuracy Studies criteria (QUADAS-2). The Web of Science ${ }^{\circledR}$ Core Collection, MEDLINE ${ }^{\circledR}$ and Scopus ${ }^{\circledR}$ databases were searched for original articles published in peer-reviewed journals with the specific keywords "colorectal cancer", "early detection", "early-stage colorectal cancer", "epigenetics", "biomarkers", "DNA methylation biomarkers", "stool or blood or tissue or biopsy", "NDRG4", "BMP3", "SEPT9", and "SDC2". Based on eligibility criteria, 74 articles were accepted for analysis. mSDC2 and mSEPT9 were frequently assessed in studies, alone or together as part of the ColoDefense panel test-the latter with the greatest performance. mBMP3 may not be an appropriate marker for detecting CRC. A panel of five methylated binding sites of the CTCF gene holds the promise for early-stage specific detection of CRC. CRC screening compliance and accuracy can be enhanced by employing a stool mt-DNA methylation test.

Keywords: colorectal cancer; biomarkers; early detection; NDRG4; BMP3; SDC2; SEPT9; CTCF

\section{Introduction}

Since its discovery, cancer has been extensively studied, and insightful physiopathological characteristics are still arising-meanwhile, inadequate invasive screening methods 
and late diagnostic drive higher mortality. Early detection of precancerous lesions might be promising for prevention, better management, and treatment. Colorectal cancer is the third most common type of cancer in the United States, with a mortality rate of 16.3 and 11.5 for males and females, respectively [1]. Detected at an early stage, the five-year survival rate in CRC is $90 \%$, while for metastatic disease it is $10 \%$ [2]. Among the risk factors associated with the onset of colorectal cancer, environmental-related factors contribute significantly, although they can be minimized through lifestyle changes. Besides environmental factors that are considered modifiable, there are a series of non-modifiable risk factors such as age and family or personal history [3].

Moreover, colorectal cancer carcinogenesis is attributed to a series of genetic mutations and epigenetic alterations. Genomic instability has key implications in CRC carcinogenesis through two main pathways: (1) chromosomal instability and (2) microsatellite instability [4]. Regarding epigenetic modifications, the most frequently referred to are (a) DNA methylation, (b) histone modification, and (c) non-coding RNAs [5].

Given the high mortality rates associated with CRC, there is an urgent need for effective screening methods to ensure early detection - the disease being curable if detected in early stages. Currently, the golden standard in CRC screening is colonoscopy. However, colonoscopy has several disadvantages responsible for low compliance despite its high sensitivity (>95\%), and its possibility for removing cancerous and precancerous lesions at the time of detection. These limitations include invasiveness, the necessity of bowel preparation, the risk of bowel perforation, and the need for sedation. Other conventional, high-sensitive screening methods-sigmoidoscopy or CT colonography-are semi-invasive tests and display specific limitations [6]. As a non-invasive alternative, the most-used method for CRC screening is fecal occult blood testing (FOBT), through several testing alternatives such as the guaiac fecal occult blood test (gFOBT) or fecal immunochemical test (FIT). Despite the non-invasive character of these screening methods, they have lower sensitivities than a colonoscopy and are mainly used for detecting advanced colorectal neoplasms [7].

The above-described limitations of current CRC screening led to the emerging need to develop new, non-invasive methods with high sensitivity and specificity. DNA methylation is a well-known epigenetic modification involved in cancer development and progression. This alteration is responsible for transcriptional silencing of tumor suppressor genes due to the aberrant methylation of 5'-C-phosphate-G-3' (CpG) islands (CGIs). Based on the possibility of detecting methylated DNA in a wide range of biological samples (blood, tissue, stool) and the fact that these epigenetic alterations occur in the early stages of CRC, identifying DNA methylation-based biomarkers is a valuable tool in the early detection of CRC. Moreover, methylation biomarkers can be used to monitor treatment and prognosis (Figure 1) [8].

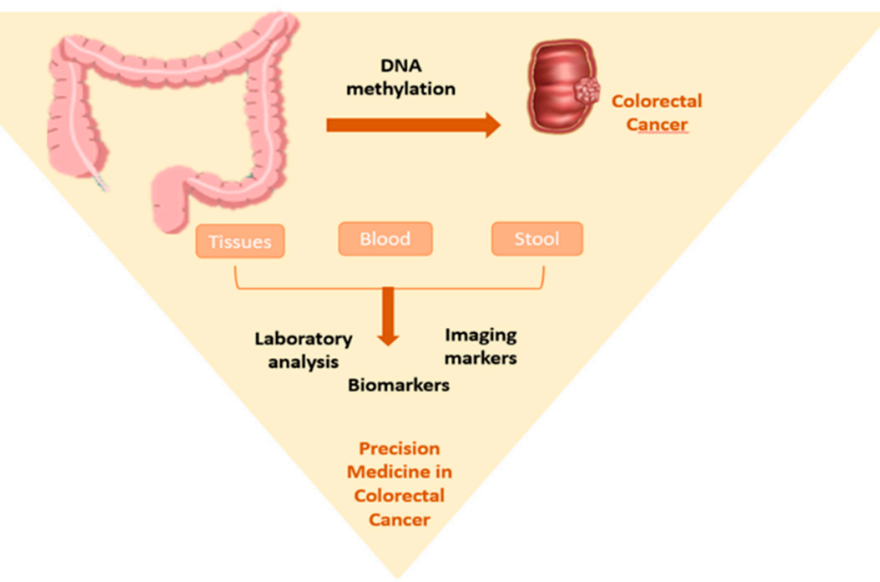

Figure 1. Emerging testing strategies in CRC based on methylated DNA biomarkers. 
New testing strategies were considered during the last decade based on DNA methylation, as the most prevalent epigenetic alteration occurring in all stages of carcinogenesis. At present, several screening kits targeting methylated genes have already been approved for use in CRC in certain countries, with acceptable sensitivity and specificity. As higher sensitivity and specificity screening methods are essential for early detection of CRC, other specific methylated genes-potential biomarkers-have been intensely investigated. However, a plethora of research is present on the topic. As the literature lacks systematic research on CRC screening using DNA methylated biomarkers, examining the new biomarkers' diversity and strength of testing is paramount to further develop optimized and validated DNA methylation tests.

In the present review, we evaluated the performance of methylated genes targeted by already approved diagnostic kits in a few countries worldwide. Subsequently, we focused on identifying new potential DNA methylation single-biomarkers or panels as promising tools in the early detection of CRC.

\section{Materials and Methods}

\subsection{Search Strategy}

We conducted a systematic literature review exploiting three main electronic libraries: Web of Science ${ }^{\circledR}$ Core Collection (Clarivate Analytics, Philadelphia/London, USA/GB), MEDLINE $^{\circledR}$ (National Library of Medicine's, Bethesda, MD, USA), and Scopus ${ }^{\circledR}$ (Elsevier, Amsterdam, NL, USA). According to the study protocol (Table S6), the study was conducted based on Preferred Reporting Items for Systematic Reviews and Meta-analyses (PRISMA) [9]. Initial requirements included open access original research published in full-text research articles in peer-reviewed academic journals during the last five years (2017-2021). We used the Boolean operator term AND to focus and narrow the search and the OR term to extend it.

We searched all fields, topic (Web of Science ${ }^{\circledR}$ ), article title, abstract, and keywords $\left(\right.$ Scopus $\left.{ }^{\circledR}\right)$. Firstly, we performed four search queries, one per each investigated biomarker (NDRG4, BMP3, SEPT9, and SDC2), using the key terms: (1) «colorectal cancer» AND « NDRG4» AND « early detection»; (2) «colorectal cancer» AND «BMP3» AND « early detection» (3) « colorectal cancer» AND «SEPT9» AND «early detection» (4) «colorectal cancer» AND «SDC2 » AND «early detection». Then, a broader search was employed: (5) «colorectal cancer» AND «epigenetics» AND «biomarkers»; (6) «colorectal cancer» AND «DNA methylation biomarkers». Finally, a more stage-specific query was addressed: (7) «early-stage colorectal cancer» AND «DNA methylation» AND «stool»; (8) «blood» OR (9) «tissue» OR (10) «biopsy» OR (11) «early detection of colorectal cancer» AND «DNA methylation biomarkers». We selected all randomized clinical trials (RCTs), clinical trials (CT), clinical case series (CCS), clinical cases (CC), reports, and preclinical studies published in the specified period in the searched databases in the English language. There was no restriction on geographical region, ethnicity, or specific population. On 10 July 2021 and 11 July 2021, we searched the Web of Science ${ }^{\circledR}$ Core Collection, and on 24 August 2021, we explored the MEDLINE ${ }^{\circledR}$ and Scopus ${ }^{\circledR}$ databases.

\subsection{Eligibility}

The included studies reported on early detection biomarkers for primary CRC and complied with the following criteria: (1) DNA methylation markers specific for precancerous lesions and/or CRC Stage 0, I, or II, (2) significant differences between early stage vs. advanced stage CRC, (3) biomarker performance assessment (e.g., sensitivity, specificity), (4) a wide variety of probes and specimens, and (5) any method for methylation status determination.

Furthermore, we excluded doctoral theses, position statements, conference abstracts, editorials, reviews (SR), meta-analyses (MA), or study protocols. We rejected articles containing no screening objective, other cancer types, other epigenetic alteration, other CRC stages (advanced CRC), no DNA methylation biomarker, an analytical approach, 
treatment evaluation, or no clinical or experimental data. However, we did a snowball search in the MA and SR for relevant original papers that fit our search criteria.

\subsection{Data Extraction, Analysis, and Quality Assessment}

Three authors independently screened and extracted relevant information from the eligible studies, including study population (country, number of subjects, age, presence of histological modification and/or colorectal cancer stage), study design, DNA methylation method, methylation levels, and assay performance in terms of sensitivity and specificity for early detection of colorectal cancer. The studies were qualified for eligibility according to pre-specified inclusion criteria. Any disagreement was discussed and resolved by further analysis and careful examination; a fourth analyst reviewed the investigators' search steps. Graphs were made using GraphPad Prism ${ }^{\circledR} 6.0$ (Graphpad ${ }^{\circledR}$ Software Inc., San Diego, CA, USA) and Excel (Microsoft Office ${ }^{\circledR}$, Albuquerque, NM, USA).

The included studies were subject to the quality assessment tool for diagnostic accuracy studies 2 (QUADAS-2) [10]. The tool was modeled for our review topic to determine the risk of bias and concerns regarding applicability over four domains: patient selection, index tests, reference standards, and flow and timing. The risk of bias and applicability concerns were rated as "High", "Low", or "Unclear" by two reviewers (S.A.A and C.B.I). Graphical representation and tabular results were made using available online templates from the University of Bristol website. Furthermore, The National Health Medical Research Council (NHMRC) Level of Evidence Hierarchy (2009) was applied to all reviewed studies [11].

\section{Results}

\subsection{Study Selection}

The search in the Web of Science ${ }^{\circledR}$ Core Collection database retrieved 451 results, in MEDLINE ${ }^{\circledR} 555$ results, and Scopus retrieved $685^{\circledR}$ results, with 1.691 articles over the three databases. After duplicate removal $(n=383), 579$ articles were screened by title, and if the title was inconclusive, the abstracts were read. After careful selection, 98 articles were chosen for full-text reading. Finally, based on our inclusion and exclusion criteria, 24 articles were eliminated, with 74 articles included in the review based on selection criteria (Figure 2).

\subsection{Colorectal Cancer, Aging, Epigenetic Clock, and DNA Methylation}

The incidence of colorectal cancer increases with age. Biological aging is associated with genomic instability, mitochondrial dysfunction, epigenetic changes, increased cellular vulnerability, and telomeric erosion [12,13].

The rate of $\mathrm{CpG}$ site methylation in gene promoters is enhanced with aging. One of CRC's characteristics is CpG island methylator phenotype (CIMP) which represents the overall hypermethylation status of specific genes that are involved in cellular growth and survival [14]. CIMP displays V-raf murine sarcoma viral oncogene homolog B (BRAF) mutations, methylated mutL homolog 1 (MLH1), and a deficient mismatch repair [15]. With age, methylation of cancer-specific genes occurs in the normal colonic mucosa of healthy subjects with no history or evidence of disease. Therefore, age-related DNA methylation predisposes to increased cancer risk [16].

One of the theories of aging proposes the existence of an epigenetic clock that englobes specific methylation signatures that can be predicted and studied through genome-wide techniques. Genomic methylation patterns can serve as biomarkers for biological aging, such that a model of the aging-specific methylome can be developed [14]. Consequently, epigenetic age estimators based on different CpG sites were discovered [17-19]. Biological age acceleration, as a difference between epigenetic and chronological age, was correlated with cancer incidence and mortality [20]. DNA methylation age (DNAmAge) is associated with CRC prognosis. Moreover, three algorithms. DNAmMRscore (DNAm mortality risk score), DNAm PhenoAge acceleration (AgeAccelPheno), and DNAm GrimAge acceleration 
(AgeAccelGrim) can be positively associated with colorectal cancer-specific mortality [21]; blood DNA methylation profiles can be measured using the Infinium Methylation EPIC BeadChip Kit that covers over 850,000 CpG sites (Illumina, Inc, San Diego, CA, USA). Three methylation-based measures of biological aging PhenoAge, GrimAge, and methylationpredicted telomere length were associated with CRC risk and other cancers such as lung, kidney, and urothelial cancer [22]. Furthermore, the epigenetic clock, PhenoAge, is suitable for high CRC risk estimation [23].

\section{Identification of studies via databases}

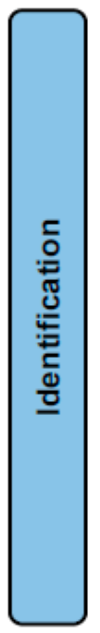

\section{Records identified from searched Databases using keywords: \\ "colorectal cancer", "early detection", "early stage} colorectal cancer", "epigenetics", "biomarkers", "DNA methylation biomarkers", "stool", "blood", "tissue", "biopsy", "NDRG4", "BMP3", "SEPT9", "SDC2"

Published during the last five years $(2017-2021)$

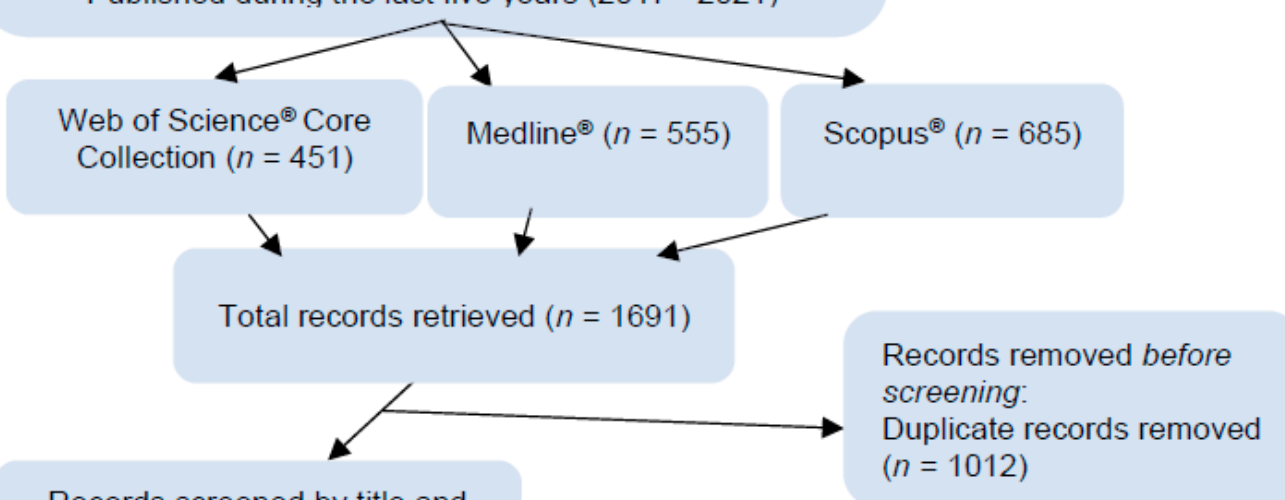

Records screened by title and abstract $(n=579)$
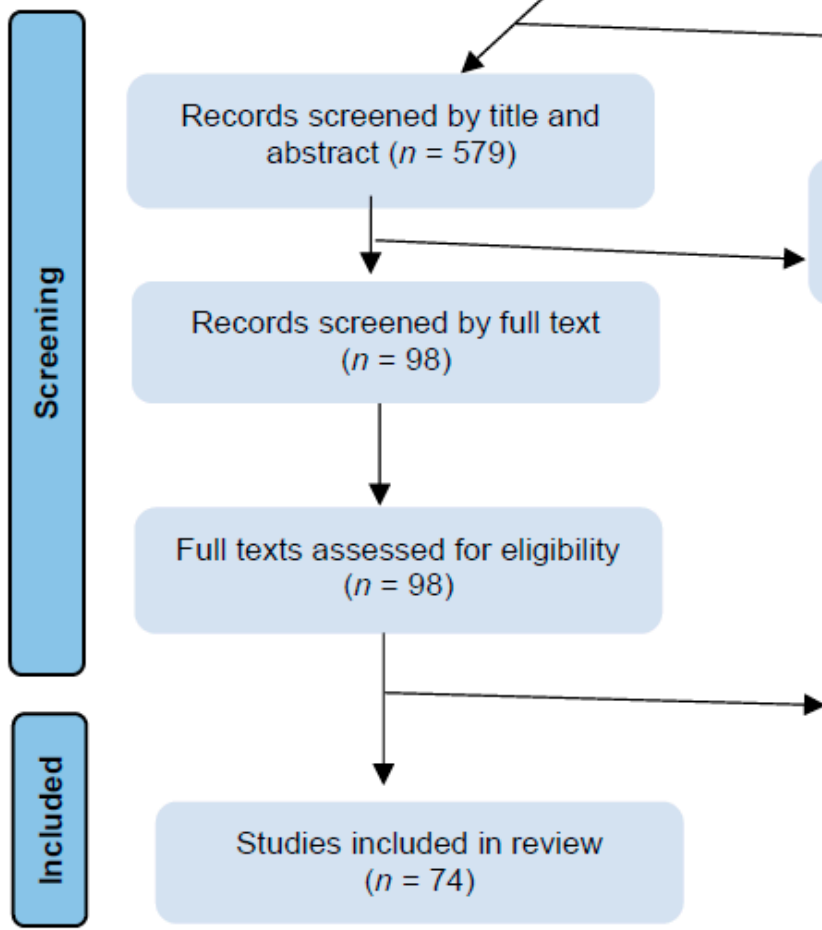

Off topic records excluded after screening the title and abstract $(n=481)$

Records screened by full text $(n=98)$

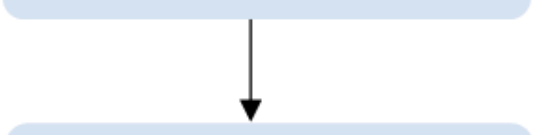

Full texts assessed for eligibility

$$
(n=98)
$$

Full texts excluded based on exclusion criteria: $n=24$

Not a screening purpose $(n=1)$

Not for early detection $(n=7)$

No difference between early and

advanced stage assessed $(n=15)$

No clinical/experimental data $(n=1)$

Studies included in review

$$
(n=74)
$$

Figure 2. Preferred Reporting Items for Systematic Review and Meta-Analysis (PRISMA) diagram illustrating the literature search process.

Long interspersed nucleotide element-1 (LINE-1) is an autonomous retrotransposon that generates new genomic insertions through the retrotransposition of an RNA intermediate. LINE-1 hypomethylation can serve as a biomarker for human aging [24,25], and is 
also associated with the early-onset of CRC [26]. The methylation status of DZIP3, an E3 ubiquitin ligase, appears to be the bridge between aging, the immune system, and CRC [13].

\subsection{Currently Approved and Known Biomarkers; High Performance, Low CRC-Specific Early Detection}

Cologuard $^{\circledR}$ is the first FDA-approved stool DNA test for average-risk CRC screening (in 2014) - a multi-target stool DNA (mt-sDNA) test with high sensitivity which analyzes several molecular markers, including N-Myc Downstream-Regulated Gene 4 Protein (NDRG4) and Bone Morphogenetic Protein 3 (BMP3) methylation status, KRAS mutation and $\beta$-actin, combined with FIT for CRC screening. Compared to other screening methods based on fecal hemoglobin detection as a single marker, the mt-sDNA test also detects mutations and DNA methylation in all stages of carcinogenesis, from premalignancy to advanced stages. In contrast, the detection of fecal hemoglobin alone is more reliable in the late stages, given the fact that precancerous lesions may not bleed $[27,28]$.

Epi proColon ${ }^{\circledR}$ is the first blood-based screening test approved by the FDA, in 2016. The test consists of a qualitative analysis based on PCR detection of methylated SEPT9 (septin 9). Methylated SEPT9 levels are significantly elevated in both tissue and blood samples from patients with CRC compared to healthy individuals, having high specificity but a lower sensitivity compared to Cologuard ${ }^{\circledR}$ and other screening methods [29]. Besides Cologuard ${ }^{\circledR}$ and Epi proColon ${ }^{\circledR}$, single-target stool DNA tests are also available for CRC screening. EarlyTect ${ }^{\mathrm{TM}}$-Colon Cancer (Genomictree, South Korea) approved by the Korean [30], and Colosafe ${ }^{\circledR}$ (Creative Biosciences China), approved by the China National Medical Products Administration are two st-sDNAs [31,32] (Table 1, Figure 3).

Table 1. List of approved CRC screening epigenetic biomarkers tests.

\begin{tabular}{cccc}
\hline Test & Year & Sample & Biomarker Target \\
\hline ColoGuard & 2014 & Stool & NDRG4, BMP3, KRAS, $\beta$-actin \\
Epi proColon ${ }^{\circledR}$ & 2016 & Blood & SEPT9 \\
EarlyTect $^{\text {TM_Colon Cancer }}$ & 2018 & Stool & SDC2 \\
Colosafe $^{\circledR}$ & & Stool & SDC2 \\
\hline
\end{tabular}

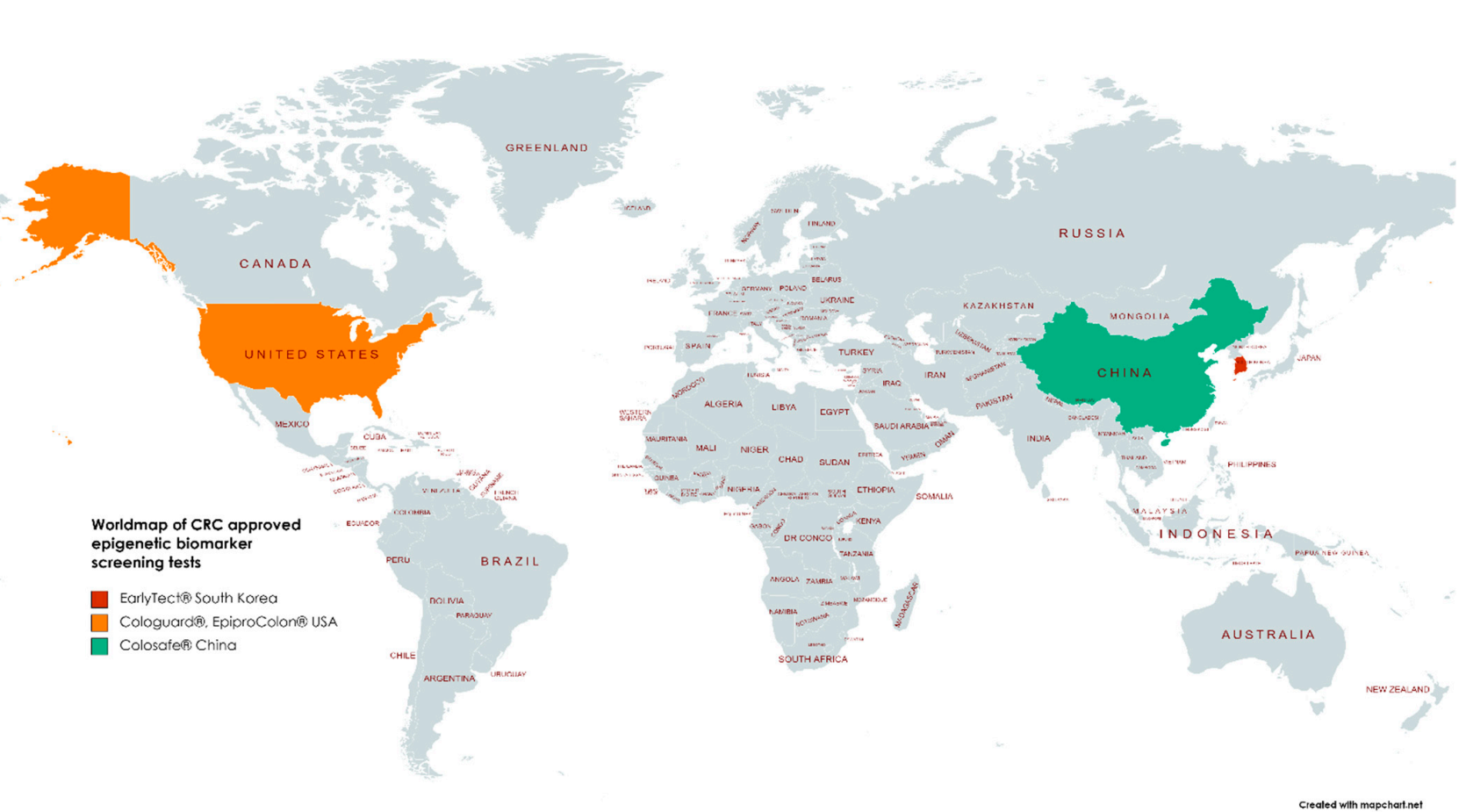

Figure 3. Map of approved epigenetic screening test kits Cologuard ${ }^{\circledR}$, Epi proColon ${ }^{\circledR}$-USA, Colosafe ${ }^{\circledR}$ China, EarlyTect $^{\circledR}$ Korea. Colodefense ${ }^{\circledR}$ (China, 2021) is used at present only for research objectives. 
We examined the last five years' literature for methylated genes currently targeted by FDA or NMPA screening kits: mSDC2, mSEPT9, mNDRG4, and mBMP3. With our specific filters, we found six studies dedicated to mSDC2 [33-38] and seven studies for mSEPT9 [39-45]; two described mBMP3 performance [46,47], while no study evaluated mNDRG4 alone. A multi-target approach evaluating these biomarkers and others was employed in 16 studies, 5 of them deciphering mSDC2 and mSEPT9 performance [48-52].

\subsubsection{Syndecan-2 (SDC2)}

SDC2 is a transmembrane protein implicated in cellular proliferation, migration, cellmatrix interaction, and angiogenesis [53]. SDC2 methylation (Table S1) was quantified in two studies using tissue and stool [33,34]; one study used tissue and bowel lavage [35], and three studies evaluated DNA methylation only in stool [36-38]. Only one study had paired samples [33]. Sensitivities for stages I/II were between 83.3-91.4\%, and 89.6-100\% for stage III/IV $[34,36,37]$. Although evaluation of SDC2 methylation is indicated for early detection of colorectal cancer, it seems that assay sensitivity is superior for stage III/IV, while for stage I/II is satisfactory, thus displaying a limited stage specificity.

\subsubsection{Septin 9 (SEPT9)}

SEPT9 belongs to the septin family, being a cytoskeleton component with GTP-binding protein activity. Therefore, it has a role in essential processes, including cell division. CpG island hypermethylation of the SEPT9 promoter leads to altered expression-eliminating its tumor suppressor activity, which contributes to carcinogenesis [54]. mSEPT9 was evaluated in four studies as a single biomarker $[39,40,42,45]$. Three studies compared mSEPT9 performance with other known screening tools [41,43,44] (Table S2). Plasma was used in six studies [39-44], while one employed a paired sample approach investigating plasma and stool samples from the same patients [45]. Epi proColon ${ }^{\circledR}$ was frequently used for plasma mSEPT9 measurement. Methylated SEPT9 in plasma samples had a higher sensitivity when compared with FOBT or known tumor protein markers-CEA and CA19-9. When combined, FOBT and mSEPT9 assessment led to maximum sensitivity $(100 \%)$ for stage I CRC [41]. Furthermore, sensitivity is higher for mSEPT9 in stool samples vs. plasma samples while having a similar specificity [45]. Some studies also evaluated mSEPT9 prognosis significance (extensively reviewed here [55]) and its role in recurrence monitoring $[40,42-44]$.

\subsubsection{Bone Morphogenetic Protein (BMP3)}

Bone morphogenetic protein (BMP3) is secreted by osteoblasts and osteocytes, contributing to bone mass regulation [56] and having an essential role in cellular development and growth. Furthermore, BMP3 promoter hypermethylation induces its inactivation with subsequent tumorigenesis implications [57]. In both studies analyzed, BMP3 was evaluated in an Iranian population; the methylation status was highest in stage IIA CRC $(66.6 \%)$, attributing a role to it in early detection [46] - although both studies showed a decrease in overall sensitivity and specificity. Furthermore, the authors concluded that BMP3 performance is not sufficient for use as a single biomarker; instead, it can be assessed with other specific methylated genes $[46,47]$.

\subsubsection{N-Myc Downstream-Regulated Gene 4 (NDRG4)}

N-Myc Downstream-Regulated Gene 4 (NDRG4), expressed within nervous system structures throughout the body, but predominantly studied in the brain and heart, was proven to be expressed explicitly in enteric neurons in a study using tissues from NDRG4 wild-type, heterozygous, and knockout mice and humans; immunoreactivity was restricted to the enteric nervous system (ENS) [58]. A recent study aiming to identify whether the ENS, via NDRG4, affects intestinal tumorigenesis showed that Ndrg4 knockdown in CRC models and in an indirect co-culture of primary enteric nervous system (ENS) cells was associated with enlarged intestinal adenoma development-the organoid growth being 
boosted by the Ndrg4-/ - ENS cell secretome- the ENS, via loss of Ndrg4, being involved in colorectal pathogenesis [59].

The reduction of ENS plexus size is accompanied by the increased number of galaninimmunoreactive neurons; the neuroprotective peptide galanin may inhibit the extrinsic pathway of apoptosis, and in this way promote (colon) cancer cell survival [60].

\subsubsection{Methylated Genes Panel Containing Approved Biomarkers}

We considered a biomarker panel any evaluation of two or more methylated genes. Most studies described ColoDefense ${ }^{\circledR}$, a yet unapproved test for clinical diagnosis, which combines mSDC2 and mSEPT9 detection [48-52] (Table S3). For stage I CRC, the ColoDefense ${ }^{\circledR}$ test showed a sensitivity between $69.2-81.8 \%$, stage II CRC $85.7-100 \%$, stage III $88.9-89.7 \%$, and stage IV $75-100 \%$. The maximum specificity was $93.2 \%$. Besides the performance evaluation of the blood ColoDefense ${ }^{\circledR}$ test, two articles had a more particular approach: (a) testing protein biomarkers concomitant with methylated SDC2 and SEPT9 [51] or (b) evaluating a possible false-positive result based on leukocyte genomic DNA [52]. Comparing sensitivities for methylated genes vs. methylated genes plus tumor-specific protein markers (CEA, AFP, CA19-9), an increase was observed (from 35.3 to $47.1 \%$ for stage $0+\mathrm{I}, 48.6$ to $74.3 \%$ for stage II, 64.0 to $80 \%$ for stage III, and 89.7 to $96.6 \%$ for stage IV) [51]. As for point (b), when mSEPT9 and $\mathrm{mSDC} 2$ were assessed from blood leukocytes, no significant difference was noticed between normal subjects vs. individuals with colorectal cancer (stages I-IV) [52]. At the same time, the ColoDefense test could differentiate CRC cases from precancerous lesions or healthy individuals [52].

Assessing DNA methylation biomarkers together with mutated ones is not uncommon. Three studies that evaluated mt-DNA tests used the same strategy as the Cologuard ${ }^{\circledR}$ test. A mNDRG4, mBMP3, and KRAS mutations, and a hemoglobin test, evaluated in a screening setting, could distinguish between different precancerous lesions and be more sensitive than FIT in detecting them [61]. A multi-faceted stool-based assay that covered three methylated biomarkers (SEPT9, NDRG4, BMP3), three mutated genes (KRAS, BRAF, PI3KCA), FIT and a bacteria level measurement of Fusobacterium nucleatum and Parvimonas micra, generated an increase in CRC detection rates from stage I to stage III, followed by a decrease in stage IV [62]. Additionally, KRAS mutations were explored together with mNDRG4, methylated tissue factor pathway inhibitor 2 (mTFPI2), and mSDC2 in an mt-DNA assay which exceeded FOBT in detecting stage I-III CRC [63].

Combined mSDC2 and mTFPI2 measurements showed a higher sensitivity for identifying adenoma and CRC. Moreover, methylation determination in stool probes outperformed FOBT and protein markers [64]. When a panel containing $\mathrm{mSDC2}$, methylated secreted frizzled-related protein 1 (mSFRP1), methylated secreted frizzled-related protein 2 (mSFRP2) and methylated proline-rich membrane anchor 1 (mPRIMA1) was investigated for detecting adenoma and CRC in plasma, a higher performance was obtained compared with each methylated gene alone [65]. Furthermore, mSDC2 and mSFRP2 can be simultaneously measured with a novel test-SpecColon-which shows an increase in sensitivity with CRC stage and is convenient to perform in advanced adenoma [66].

Multiplexing SEPT9 with O-6-methylguanine-DNA methyltransferase (MGMT) and Ras association domain family 1 -isoform A (RASSF1A) evidences an increase in sensitivity with a decrease in specificity for CRC. As for stages I and II, a sensitivity of $100 \%$ is reached, pointing to a key role in early detection [67]. A developed model comprising of SDC2, SEPT9, and five other hypermethylated gene promoter regions - homeobox protein aristaless-like 4 (ALX4), BMP3, Neuronal Pentraxin 2 (NPTX2), Retinoic Acid Receptor Beta (RARB), and vimentin (VIM) — displayed an early-stage specific performance [68]. A panel of 80 methylation markers including SEPT9, IKAROS family zinc finger 1 (IFZF1), Branched chain amino acid transaminase 1 (BCAT1), vimentin (VIM), and others, displayed a sensitivity of $74 \%$ and a specificity of $90 \%$ for identifying early-stage CRC [69].

NDRG4, BMP3, SEPT9, and SDC2 were evaluated in two studies [70,71]. The former study found that mBMP3 detection is unsuitable for colorectal cancer diagnostics due to 
its decreased methylation frequency in tissue or stool samples [70]. However, the latter showed an improved performance by exploiting a merged assay in stool samples by sDNA-FOBT (DNA methylation markers BMP3, NDRG4, SDC2 together with FOBT) [71].

\subsection{Promising Biomarkers in Early Screening of Colorectal Cancer, a Step Forward towards a Precision Medicine Approach}

Several studies investigated potential new biomarkers in the early screening of colorectal cancer. As single biomarkers, CLIP4 was evaluated in one study [72], TWIST1 in three articles [73-75], and LINE-1 in two [76,77]. A panel of methylated biomarkers was also employed-C9orf50 was assessed together with CLIP4 and KCNQ5 [78], with TWIST1 [79] or just with KCNQ5 [80]. Other potential biomarkers and their performance are displayed in Table S4 [81-90].

\subsubsection{CAP-Gly Domain Containing Linker Protein Family Member 4 (CLIP4)}

The mammalian cytoplasmic linker protein (CLIP)-170 (CLIP 1-4) links the microtubule plus ends to kinomeres, endocytosis vesicles, and the steering brink of migrating cells. Recent studies have shown that methylated CAP-Gly domain containing linker protein family member 4-CLIP4, may be a potential biomarker for early detection of CRC. An mCLIP4 assay was carried out on stool and tissue samples, showing a sensitivity of $90.3 \%$ and specificity of $88.4 \%$ (Figure 4 ) [72,78].

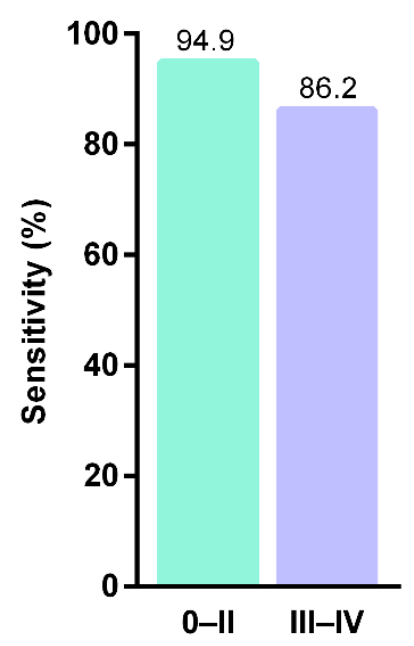

Figure 4. Sensitivities of stool mCLIP4 test in detecting different CRC stages (after Cao et al., 2021) [72].

\subsubsection{Alpha 1-Antitrypsin (A1AT)}

Another study highlights alpha 1-antitrypsin (A1AT) as a potential biomarker in colorectal cancer detection. Plasma concentrations were measured for both CEA and A1AT, in healthy and CRC patients. Plasma concentrations of A1AT were correlated with tumor stage, and A1AT determination had better sensitivity and specificity than CEA for early detection of CRC. A1AT is highly expressed in inflammation, mainly when localized at hepatocytes. This gene is also expressed in colonic tumor cell lines. Some studies have suggested an increase in A1T1 in cancers such as those of the pancreas, breast, and liver [91].

\subsubsection{Zinc-Finger Protein CCCTC-Binding Factor (CTCF)}

The five potential zinc-finger protein CCCTC-binding factors function as transcriptional activator, repressor, or insulator proteins; CTCF_33, CTCF_55, CTCF_94, CTCF_113, and CTCF_13 biomarkers analyzed in a study from China showed better performance than two well-known methylation biomarkers, NDRG4 and BMP3. Furthermore, with a sensitivity of $93.54 \%$ and a specificity of $94.05 \%$ (Figure 5), CTCF-binding sites may be possible biomarkers in colorectal cancer detection [92]. 


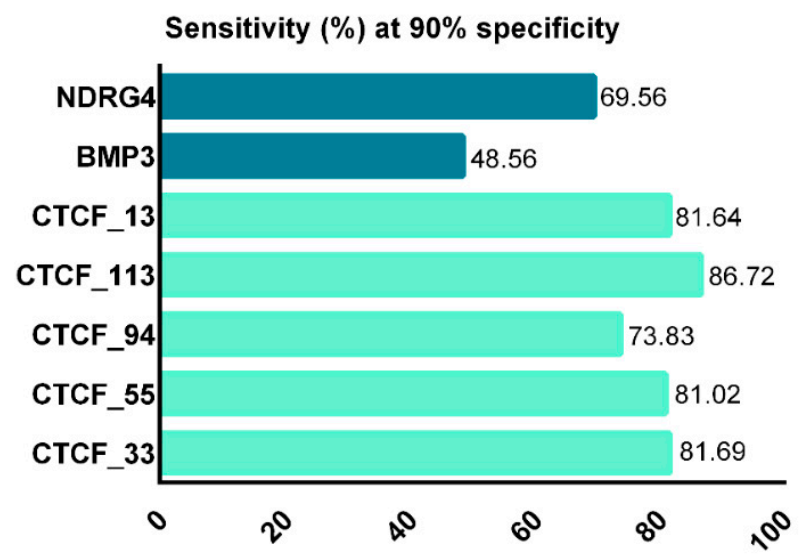

Figure 5. Comparison of CTCF-binding site markers with existing markers (after Liu et al., 2017) [92].

\subsubsection{Metallophosphoesterase Domain Containing 2 (MPPED2) Gene}

The MPPED2 gene regulates many cellular functions, including differentiation, proliferation, and cellular apoptosis-well known for the link between their malfunctioning and cancer pathogenicity. Gu et al. indicate that epigenetic changes in the MPPED2 promoter region are encountered during colorectal cancer. The study included (a) a group with colorectal tissue lesions, (b) a group with polyps, and (c) a group with adenoma, (d) primary carcinomas, and (e) normal tissues. The study results indicated that hypermethylation of MPPED2 promoter is common in CRC. The methylation state of MPPED2 showed an exponentially increase between colorectal lesions groups from $5.58 \%$ (polyps) to $14.5 \%$ (adenoma) and 30.56\% (carcinoma). Taking these results into account, methylated MPPED2 could be a promising biomarker for the early diagnosis of CRC [93].

\subsubsection{Smooth Muscle Protein $22 \alpha$ (SM22 $\alpha$ )}

The link between protein expression and the methylation status of the smooth muscle protein $22 \alpha$ (SM22 $\alpha$ ) was investigated in 78 cases of CRC. The results were promising, showing that the methylation level of the SM22 $\alpha$ promoter is higher in CRC tissues compared to control samples. Furthermore, hypermethylation of the SM22 $\alpha$ gene may occur in the early stages of CRC, so it may be a biomarker in diagnosis of CRC [94].

\subsubsection{Transmembrane Protein 240 (TMEM240)}

To date, the role of TMEM240 in cancer pathogenicity has not been completely elucidated. Chang et al. investigated the relationship between expression and methylation status with CRC. Hypermethylation of TMEM240 in tumor tissues was increased compared to normal tissues. Low expression of the TMEM240 protein has been observed in about half of patients with inflammatory bowel diseases, which have a three to five times higher risk of developing colorectal cancer. The study's results showed that hypermethylation and low expression of TMEM240 are potential biomarkers for colorectal cancer detection, poor prognosis, and early recurrence prediction [95].

\subsubsection{Potassium Calcium-Activated Channel Subfamily M Alpha 1 (KCNMA1)}

KCNMA1 encodes the $\alpha$-subunit of the large conductance, voltage, and Ca2+-activated (BK) potassium channel; it is widely distributed across tissues, including both excitable and non-excitable cells [96]. Basie et al. have extensively studied the expression of the KCNMA1 gene associated with colorectal cancer. It has been observed that in patients with colorectal cancer, levels of KCNMA1 are considerably low due to methylation, without being able to distinguish between cancer stages. Therefore, some validation studies may be required on the use of KCNMA1 as a biomarker in detecting CRC [97]. 


\subsubsection{Long Interspersed Nuclear Element-1 (LINE-1)}

Current studies have shown that analysis of LINE-1 methylation levels in circulatory DNA could discriminate lung cancer patients from patients with chronic inflammatory lung diseases [98]. Therefore, the assessment of methylated LINE-1 may serve as a valuable tool for cancer screening. Two studies also evaluated hypomethylation of long interspersed nuclear element-1 (LINE-1) as a potent early detection biomarker in CRC [76,77]. Measurement of cell-free DNA long interspersed nuclear element- 1 hypomethylation index (cfDNA LHI) was achieved with $63.2 \%$ sensitivity and $90 \%$ specificity for early-stage I/II CRC [76]. In addition, LHI can differentiate between types of histological alteration by having a directly proportional relationship with malignancy degree [77]. Values of LHI increase in the following order: healthy subjects, non-advanced adenoma (NAA), advanced adenoma (AA), adenocarcinoma (AC) [77].

\subsubsection{Other Potential Biomarkers in Literature}

In 2019, a study correlated the link between androgen receptor AR () and colorectal cancer risk in 378 patients. AR hypomethylation in young patients (under the age of 60 ) increases the risk of CRC. The explanation may be that in young patients, androgen levels are higher, the occurrence of hypomethylated AR is higher, and thus the risk of CRC increases [99]. Glycoprotein nmb (GPNMB) was analyzed from cancerous tissue samples $(n=20)$, non-advanced adenoma tissues $(n=21)$, advanced adenoma $(n=48)$, and normal tissue $(n=20)$. The methylation status of the GPNMB gene can be used to track the progression of colorectal lesions [100]. Hypermethylation of three genes HOXA2, HOXA5, and HOXA6 is detected in CRC patients, with HOXA5 having the highest methylation status [101].

In CRC, Glutamate Ionotropic Receptor AMPA Type Subunit 4 (GRIA4), Solute Carrier Family 8 Member A1 (SLC8A1), and Synapsin III (SYN3) have a higher methylation degree in tissue, stool, and cfDNA [102]. Methylated Solute Carrier Family 30 Member 10 (SLC30A10), claudin 1 CLDN1, and Inhibin Subunit Beta A (INHBA) were evidenced by SureSelectXT Methyl-Seq as being able to differentiate between normal and tumor tissue [103]. Two CpG sites in the promoter region of KIAA1549L are hypermethylated in CRC, pointing to a potential early detection specific biomarker [104]. Also, two CpGs (cg09239744 and cg12587766) may be used for diagnostic CRC [105]. The age of CRC onset has decreased a lot over the last decade. Hence, an increased survival rate can be reached by early diagnosis and prompt action. Recent studies focused on potential biomarkers that can be used in medical practice for the early detection of CRC, which may include the above-mentioned genes or others such as UNC5D, KCNA1 [106], FMN2 [107], JAM3 [108], GSDME [109], CRF [110], SMAD3 [111], SCTR [112], CNRIP1 [113], NEUROG1 [114], and p16 [115].

\subsubsection{Quality Assessment of the Included Studies}

Quality assessment results using the QUADAS-2 tool are shown below as a summary graph (Figure 6), and in Table S5, tabular results are presented. The patient selection domain shows the highest potential risk of bias due to the case-control study design. The index test rated unclear risk of bias in 39/74 studies, followed by 32 studies which were scored as having a high potential risk of bias considering their ambiguity or lack of information regarding blinding, performing the test as per the manufacturer's guidelines, or setting a cut-off value. For most of the studies (54/74), if colonoscopy was used as the reference standard, the risk of bias was considered low, while an unclear rating was giving for any uncertainty concerning colonoscopy assessment prior to methylation assays. The flow and timing domain was judged as having a low risk of bias in 45 studies. Applicability concerns were serious for patient selection because included studies employed a clinical setting rather than a screening one. 


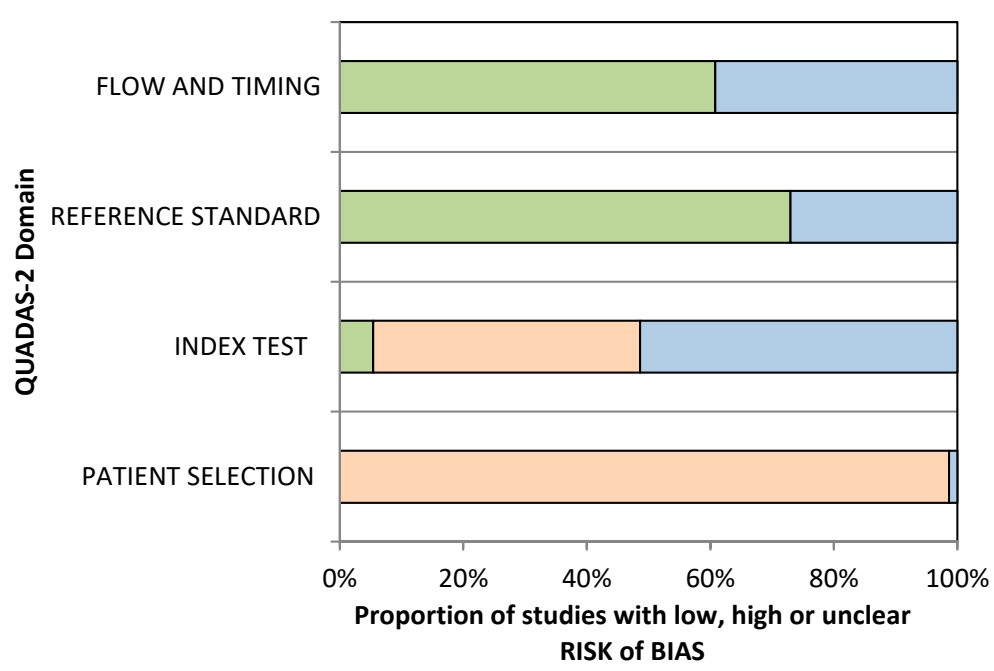

$\square$ Low $\square$ High $\square$ Unclear

Figure 6. QUADAS-2 quality assessment overview for the included studies.

Level of evidence and grade of recommendation for each included study are shown in Table S5. As already mentioned, our database search did not retrieve RCTs, but casecontrol studies. Based on the NHMRC Evidence Hierarchy, a level of evidence of III-2 was observed in 66/74 studies (Figure 7A) due to lack of an independent, blinded comparison between methylated DNA test and colonoscopy, as it has not been employed or reported. Only two studies were classified as evidence level II. As for grade of recommendation, C was scored frequently (53/74; Figure 7B), in accordance with the bias assessment and evidence level of reviewed studies.

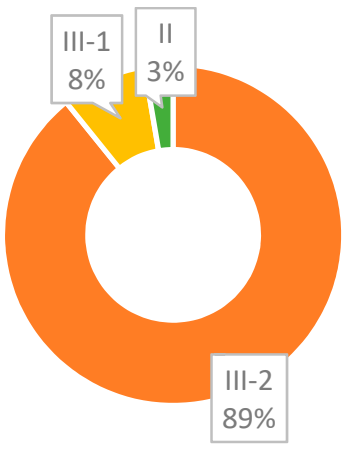

(A)

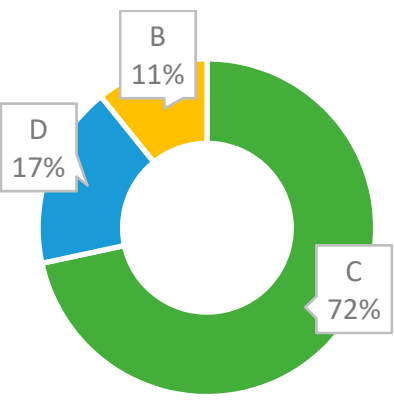

(B)

Figure 7. (A). III-2 accounts for the majority of 'Evidence for Outcome-Level (Quality) of evidence for diagnostic tests" (NHMRC Evidence Hierarchy). (B) C accounts for the majority of grades (Strength) of recommendation.

\section{Discussion}

Cancer is considered a genomic disease with complex occurrence mechanisms, such as defective cellular apoptosis, which causes uncontrolled cell proliferation. Moreover, in the case of colorectal cancers, each tumor has an unique genetic signature. Specific cancer genes are brought to the fore: oncogenes (these genes are encoded by alterations) and tumor suppressor genes (these genes are inactivated in tumorigenesis). Oncogenes can encode factors that influence cell survival and proliferation. In contrast, tumor suppressor genes limit proliferation, growth, motility, and cell invasion. The inactivation of tumor suppressor genes can occur by mutations and promoter methylation [116].

The molecular hallmarks of CRC are microsatellite instability (MSI), chromosomal instability, and $\mathrm{CPG}$ island methylator phenotype (CIMP). In the path of chromosomal instability an activation of the KRAS and BRAF genes occurs, along with an inactivation of the tumor suppressor genes, TP53 and APC, and loss of heterozygosity for the long 
arm of chromosome 18. All these sub-cellular events generate the phenotypically-healthy genetically-mutated cells to transform into cancer cells. The TP53 gene, called the genome guard, has a role in senescence, cellular apoptosis, and DNA repair. In more than 50\% of colorectal cancer cases, the TP53 gene is mutated. Fearon and Vogelstein proposed a model in which the suppressor genes APC, DCC, p53, and oncogene KRAS are involved. Chromosomal changes involve the arms of the $8 p, 5 q, 18 q$, and 17p chromosomes. In the first stage, the inactivation of the APC gene led to the appearance of adenoma in the normal colon mucosa; the growth of adenoma is correlated with the appearance of KRAS mutations, localized on the chromosome $12 p$, subsequently resulting in genetic changesespecially deletions of the genes on chromosome 18q. DCC is located on chromosome 18q; approximately $70 \%$ of colorectal cancer cases predicted allelic losses of DCC. In the Fearon and Vogelstein model, in the process of transition from adenoma to cancer, mutation or loss of p53 on 17p appeared [117].

A typical path in sporadic colorectal cancers is the microsatellite instability (MSI) pathway which involves a huge accumulation of mutations. MSI occurs due to an inactivation/disturbance at the level of the DNA replication error repair system (MMR), which is responsible for supervising and correcting errors introduced in microsatellites. Microsatellites are repetitive sequences of DNA; fluctuations in the length of the microsatellite, called instability, can mean that the genes repairing replication errors do not work correctly. Faulty repair of replication errors is mainly caused by a methylation anomaly of the MLH1 replication error repair gene, being a sporadic process without the involvement of heredity. Another mechanism may be a mutation of a hereditary nature, if the error-repair genes (MLH1, MSH2, MSH6) produce a genetic predisposition to CRC [118].

Our study evaluated the currently used methylated genes' performance and identified various potential biomarkers that can be used for early diagnosis. Approved test kits targeting epigenetic markers can be improved using a merged assay (a molecular one, such as SDC2 with SEPT9 plus a human hemoglobin test, for example). Cologuard ${ }^{\circledR}$ already uses this approach, but taking into account that it was the first FDA-approved DNA stool test, it has a decreased performance (compared with the golden standard) — mainly because of methylated NDRG4 and BMP3. BMP3 performance is not satisfactory for use as a single biomarker [46,47]. Furthermore, its methylation levels were reduced or even undetectable in CRC patients, further reinforcing the examination of current data [70].

Using multiple markers or a methylation panel for screening may improve specific characteristics of non-invasive screening procedures. For example, multiplex detection of mSDC2 and mSEPT9 (Colodefense ${ }^{\circledR}$ test) shows high sensitivity and specificity compared with each marker alone, independently of the CRC stage. Nevertheless, the methylation status of currently used biomarkers increases with tumor size or disease progression, making them suitable for screening, diagnostics, and prognostics, but not necessarily for CRC early detection specifically. In contrast, methylated CTCF-binding sites showed an increased accuracy for detecting early-stage CRC. In addition, the assessment of each mCTCF-binding site exhibited higher sensitivity and specificity for stage I-II than for terminal stages. Moreover, when a panel of five mCTCF-binding sites was examined, a sensitivity of $91.67 \%$ and a specificity of $94.05 \%$ were recorded for adenomas, pointing towards a more precise early-stage biomarker [92].

A potential misinterpretation of CRC screening results may arise from sample type. Tests for detecting DNA methylation can be performed on tissue, blood, stool, or even urine. Stool DNA represents the sample of choice for CRC screening because tumor-circulating DNA (ctDNA) originates directly from the tumor tissue, while ctDNA from plasma may degrade over time [119]. As reported, mSEPT9 was evaluated from stool and plasma samples, the latter determination leading to a lower value that does not accurately reflect SEPT9 methylation grade [45].

Most studies reviewed here used qMSP (quantitative methylation-specific PCR) for DNA methylation measurement, bisulfite pyrosequencing, or LTE-qMSP. PCR data analysis is dependent on the chosen algorithm, which dictates the balance between sensitivity or 
specificity. It is essential to exclude negative subjects for early detection, implying high specificity as a requirement and assaying more than one PCR replicate [120]. Articles included in this study followed different algorithms, explaining the observed differences in assay performance for the same biomarker. A more standardized, precise approach is needed to overcome these dissimilarities.

Our study has some limitations. Firstly, we systematically searched three databases, none of which screened running clinical trials. We did not searched all available libraries, thus a probability of missing some relevant studies exists. Some studies were excluded because performance parameters were not reported, and we did not have the appropriate tools to calculate them. We excluded research that investigated several types of cancer simultaneously, including CRC, as not being exclusively focused on CRC screening; future research may focus on multiple-target cancer screening using epigenetic biomarkers. Studies reviewed here usually followed a case-control design with inferior strength due to the low sample size and overall methodology. Additionally, a more robust statistical approach could not be addressed because of data heterogeneity.

\section{Conclusions}

This study offers a valuable information source for further investigation and exploration of early detection biomarkers for CRC. We displayed approved markers' performances using a gene-specific methylation approach and discussed potential screening biomarkers (CLIP4, A1AT, MPPED2, C9orf50, KCNQ5, and others), covering the last five years in the literature. Moreover, we could not emphasize enough the need for updates in present CRC screening guidelines regarding non-invasive methods.

Supplementary Materials: The following are available online at https: / www.mdpi.com/article / 10.3390/cancers13194965/s1, Table S1: SDC2 performance in multiple studies, Table S2: mSEPT9 performance comparison with other screening methods, Table S3: SEPT9 and SDC2 (Colodefense ${ }^{\circledR}$ test) performance in multiple studies, Table S4: Potential biomarker performance in multiple studies, Table S5: Quality assessments of studies. QUADAS2-LoE-GoR, Table S6: Research strategy (Annex 1).

Author Contributions: Conceptualization, A.L.P. and S.A.A.; methodology, A.L.P., I.L. and S.A.A.; software, I.L., C.-B.I.-M., S.A.A.; validation, A.L.P, and S.A.A.; formal analysis, I.L., C.-B.I.-M., and S.A.A.; investigation, I.L., C.-B.I.-M., and S.A.A.; data curation, I.L., A.L.P., C.-B.I.-M., and S.-A.A; writing-original draft preparation, I.L., C.-B.I.-M., and S.A.A.; writing-review and editing, A.L.P. and S.A.A.; visualization, S.A.A., C.-B.I.-M., A.L.P. and I.L.; supervision, A.L.P. project administration, A.L.P. All authors have read and agreed to the published version of the manuscript.

Funding: This research received no external funding.

Institutional Review Board Statement: Not applicable.

Informed Consent Statement: Not applicable.

Conflicts of Interest: The authors declare no conflict of interest.
Abbreviations
5hmC 5-Hydroxymethylcytosine
A1AT Alpha 1-antitrypsin
AA Advanced adenoma
ADHFE1 Alcohol Dehydrogenase Iron Containing 1
AFP Alpha-fetoprotein
AR Androgen Receptor
BMP3 Bone Morphogenetic Protein 3
C9orf50 Chromosome 9 Open Reading Frame 50
CA19-9 Carbohydrate antigen 19-9
CCCTC Zinc-finger protein CCCTC-binding factor 


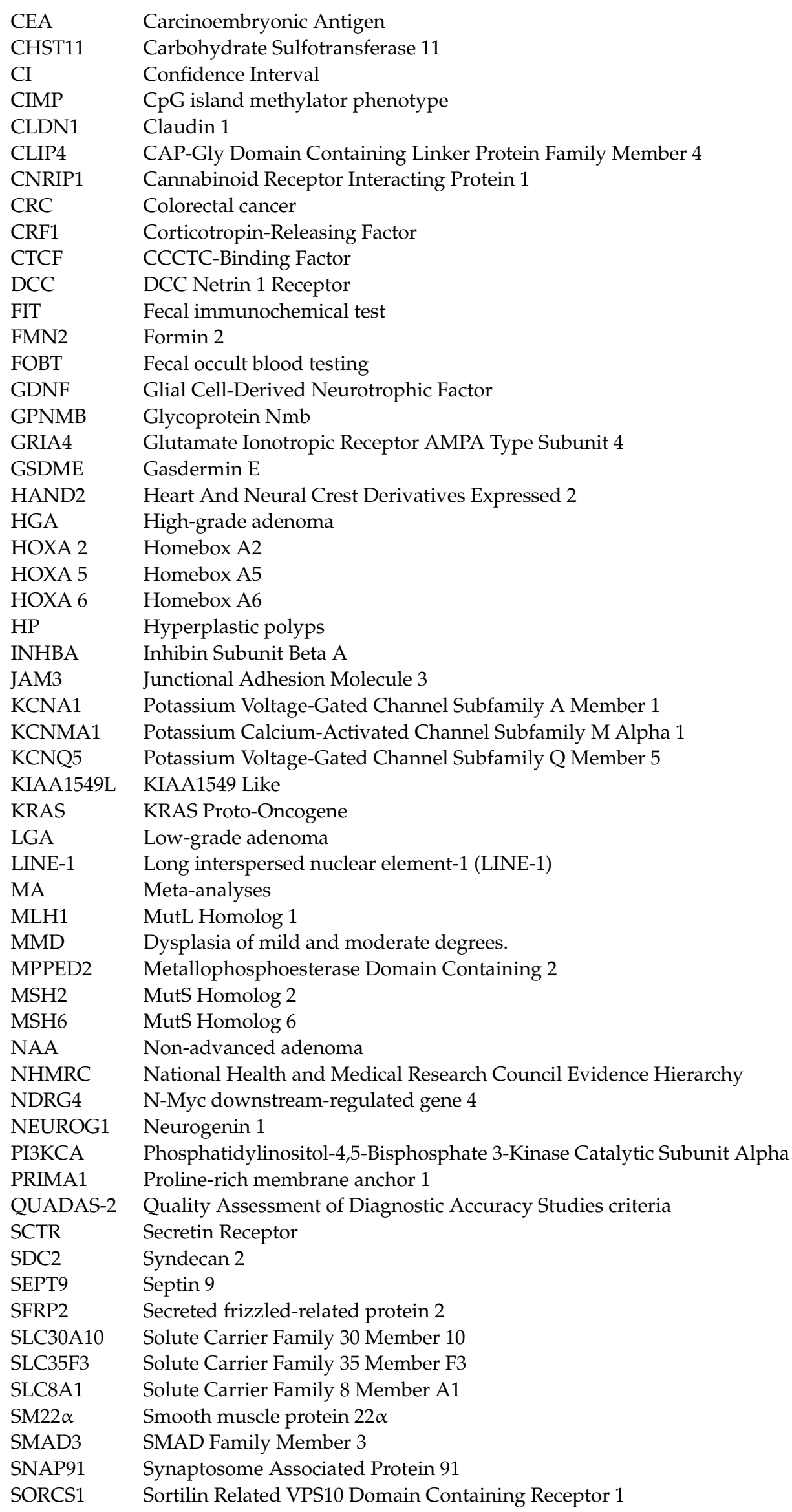




$\begin{array}{ll}\text { SP } & \text { Small polyps } \\ \text { SYN3 } & \text { Synapsin III } \\ \text { TFPI2 } & \text { Tissue factor pathway inhibitor 2 } \\ \text { TMEM240 } & \text { Transmembrane Protein 240 } \\ \text { TP53 } & \text { Tumor Protein P53 } \\ \text { TWIST 1 } & \text { Twist Family BHLH Transcription Factor 1 } \\ \text { UNC5D } & \text { Unc-5 Netrin Receptor D } \\ \text { VIPR2 } & \text { Vasoactive Intestinal Peptide Receptor 2 }\end{array}$

\section{References}

1. Siegel, R.L.; Miller, K.D.; Fuchs, H.E.; Jemal, A. Cancer Statistics, 2021. CA Cancer J. Clin. 2021, 71, 7-33. [CrossRef]

2. Kuipers, E.J.; Grady, W.M.; Lieberman, D.; Seufferlein, T.; Sung, J.J.; Boelens, P.G.; van de Velde, C.J.; Watanabe, T. Colorectal cancer. Nat. Rev. Dis. Primers 2015, 1, 15065. [CrossRef] [PubMed]

3. Rasool, S.; Kadla, S.A.; Rasool, V.; Ganai, B.A. A comparative overview of general risk factors associated with the incidence of colorectal cancer. Tumour Biol. 2013, 34, 2469-2476. [CrossRef] [PubMed]

4. Hong, S.N. Genetic and epigenetic alterations of colorectal cancer. Intest. Res. 2018, 16, 327-337. [CrossRef] [PubMed]

5. Okugawa, Y.; Grady, W.M.; Goel, A. Epigenetic Alterations in Colorectal Cancer: Emerging Biomarkers. Gastroenterology 2015, 149, 1204-1225.e12. [CrossRef]

6. Simon, K. Colorectal cancer development and advances in screening. Clin. Interv. Aging 2016, 11, 967-976. [CrossRef] [PubMed]

7. Allison, J.E.; Sakoda, L.C.; Levin, T.R.; Tucker, J.P.; Tekawa, I.S.; Cuff, T.; Pauly, M.P.; Shlager, L.; Palitz, A.M.; Zhao, W.K.; et al. Screening for colorectal neoplasms with new fecal occult blood tests: Update on performance characteristics. J. Natl. Cancer Inst. 2007, 99, 1462-1470. [CrossRef]

8. Symonds, E.L.; Pedersen, S.K.; Murray, D.; Byrne, S.E.; Roy, A.; Karapetis, C.; Hollington, P.; Rabbitt, P.; Jones, F.S.; LaPointe, L.; et al. Circulating epigenetic biomarkers for detection of recurrent colorectal cancer. Cancer 2020, 126, 1460-1469. [CrossRef]

9. Page, M.J.; McKenzie, J.E.; Bossuyt, P.M.; Boutron, I.; Hoffmann, T.C.; Mulrow, C.D.; Shamseer, L.; Tetzlaff, J.M.; Akl, E.A.; Brennan, S.E.; et al. The PRISMA 2020 statement: An updated guideline for reporting systematic reviews. BMJ 2021, 372, n71. [CrossRef]

10. Whiting, P.F.; Rutjes, A.W.; Westwood, M.E.; Mallett, S.; Deeks, J.J.; Reitsma, J.B.; Leeflang, M.M.; Sterne, J.A.; Bossuyt, P.M.; The QUADAS-2 Group. QUADAS-2: A revised tool for the quality assessment of diagnostic accuracy studies. Ann. Intern. Med. 2011, 155, 529-536. [CrossRef]

11. National Health Medical Research Council. NHMRC Additional Levels of Evidence and Grades for Recommendations for Developers of Guidelines; NHMRC: Canberra, Australia, 2009.

12. Hägg, S.; Jylhävä, J. Should we invest in biological age predictors to treat colorectal cancer in older adults? Eur. J. Surg. Oncol. 2020, 46, 316-320. [CrossRef]

13. Quan, Y.; Liang, F.; Wu, D.; Yao, X.; Hu, Z.; Zhu, Y.; Chen, Y.; Wu, A.; Tang, D.; Huang, B.; et al. Blood Cell DNA Methylation of Aging-Related Ubiquitination Gene DZIP3 Can Predict the Onset of Early Stage Colorectal Cancer. Front. Oncol. 2020, 10, 544330. [CrossRef]

14. Maugeri, A.; Barchitta, M.; Magnano San Lio, R.; Li Destri, G.; Agodi, A.; Basile, G. Epigenetic Aging and Colorectal Cancer: State of the Art and Perspectives for Future Research. Int. J. Mol. Sci. 2021, 22, 200. [CrossRef]

15. Zarkavelis, G.; Boussios, S.; Papadaki, A.; Katsanos, K.H.; Christodoulou, D.K.; Pentheroudakis, G. Current and future biomarkers in colorectal cancer. Ann. Gastroenterol. 2017, 30, 613-621. [CrossRef] [PubMed]

16. Tao, Y.; Kang, B.; Petkovich, D.A.; Bhandari, Y.R.; In, J.; Stein-O’Brien, G.; Kong, X.; Xie, W.; Zachos, N.; Maegawa, S.; et al. Aging-like Spontaneous Epigenetic Silencing Facilitates Wnt Activation, Stemness, and BrafV600E-Induced Tumorigenesis. Cancer Cell 2019, 35, 315-328.e6. [CrossRef] [PubMed]

17. Hannum, G.; Guinney, J.; Zhao, L.; Zhang, L.I.; Hughes, G.; Sadda, S.; Klotzle, B.; Bibikova, M.; Fan, J.-B.; Gao, Y.; et al. Genome-wide methylation profiles reveal quantitative views of human aging rates. Mol. Cell 2013, 49, 359-367. [CrossRef] [PubMed]

18. Horvath, S. DNA methylation age of human tissues and cell types. Genome Biol. 2013, 14, R115. [CrossRef]

19. Weidner, C.I.; Lin, Q.; Koch, C.M.; Eisele, L.; Beier, F.; Ziegler, P.; Bauerschlag, D.O.; Jöckel, K.H.; Erbel, R.; Mühleisen, T.W.; et al. Aging of blood can be tracked by DNA methylation changes at just three CpG sites. Genome Biol. 2014, 15, R24. [CrossRef] [PubMed]

20. Zheng, Y.; Joyce, B.T.; Colicino, E.; Liu, L.; Zhang, W.; Dai, Q.; Shrubsole, M.J.; Kibbe, W.A.; Gao, T.; Zhang, Z.; et al. Blood Epigenetic Age may Predict Cancer Incidence and Mortality. EBioMedicine 2016, 5, 68-73. [CrossRef]

21. Gào, X.; Zhang, Y.; Boakye, D.; Li, X.; Chang-Claude, J.; Hoffmeister, M.; Brenner, H. Whole blood DNA methylation aging markers predict colorectal cancer survival: A prospective cohort study. Clin. Epigenet. 2020, 12, 184. [CrossRef]

22. Dugué, P.-A.; Bassett, J.K.; Wong, E.M.; Joo, J.E.; Li, S.; Yu, C.; Schmidt, D.F.; Makalic, E.; Doo, N.W.; Buchanan, D.D.; et al. Biological Aging Measures Based on Blood DNA Methylation and Risk of Cancer: A Prospective Study. JNCI Cancer Spectr. 2021, 5, pkaa109. [CrossRef] 
23. Wang, T.; Maden, S.K.; Luebeck, G.E.; Li, C.I.; Newcomb, P.A.; Ulrich, C.M.; Joo, J.H.E.; Buchanan, D.D.; Milne, R.L.; Southey, M.C.; et al. Dysfunctional epigenetic aging of the normal colon and colorectal cancer risk. Clin. Epigenet. 2020, 12, 3-11. [CrossRef]

24. Erichsen, L.; Beermann, A.; Arauzo-Bravo, M.J.; Hassan, M.; Dkhil, M.A.; Al-Quraishy, S.; Hafiz, T.A.; Fischer, J.C.; Santourlidis, S. Genome-wide hypomethylation of LINE-1 and Alu retroelements in cell-free DNA of blood is an epigenetic biomarker of human aging. Saudi J. Biol. Sci. 2018, 25, 1220-1226. [CrossRef]

25. Mahmood, W.; Erichsen, L.; Ott, P.; Schulz, W.A.; Fischer, J.C.; Arauzo-Bravo, M.J.; Bendhack, M.L.; Hassan, M.; Santourlidis, S. Aging-associated distinctive DNA methylation changes of LINE-1 retrotransposons in pure cell-free DNA from human blood. Sci. Rep. 2020, 10, 22127. [CrossRef] [PubMed]

26. Akimoto, N.; Zhao, M.; Ugai, T.; Zhong, R.; Lau, M.C.; Fujiyoshi, K.; Kishikawa, J.; Haruki, K.; Arima, K.; Twombly, T.S.; et al. Tumor Long Interspersed Nucleotide Element-1 (LINE-1) Hypomethylation in Relation to Age of Colorectal Cancer Diagnosis and Prognosis. Cancers 2021, 13, 2016. [CrossRef] [PubMed]

27. Duran-Sanchon, S.; Moreno, L.; Augé, J.M.; Serra-Burriel, M.; Cuatrecasas, M.; Moreira, L.; Castells, A. Identification and validation of microRNA profiles in fecal samples for detection of colorectal cancer. Gastroenterology 2020, 158, 947-957. [CrossRef]

28. Kim, J.H.; Park, S.C. Syndecan-2 Methylation as a New Biomarker for Early Detection of Colorectal Neoplasm. Gut Liver 2018, 12, 479-480. [CrossRef]

29. Lamb, Y.N.; Dhillon, S. Epi proColon ${ }^{2} 2.0$ CE: A Blood-Based Screening Test for Colorectal Cancer. Mol. Diagn. Ther. 2017, 21, 225-232. [CrossRef] [PubMed]

30. Beltrán-García, J.; Osca-Verdegal, R.; Mena-Mollá, S.; García-Giménez, J.L. Epigenetic IVD Tests for Personalized Precision Medicine in Cancer. Front. Genet. 2019, 10, 621. [CrossRef]

31. Ferrari, A.; Neefs, I.; Hoeck, S.; Peeters, M.; Van Hal, G. Towards Novel Non-Invasive Colorectal Cancer Screening Methods: A Comprehensive Review. Cancers 2021, 13, 1820. [CrossRef] [PubMed]

32. Wang, Z.; Shang, J.; Zhang, G.; Kong, L.; Zhang, F.; Guo, Y.; Dou, Y.; Lin, J. Evaluating the clinical performance of a novel dual-target stool DNA test for colorectal cancer detection. medRxiv 2021. [CrossRef]

33. Niu, F.; Wen, J.; Fu, X.; Li, C.; Zhao, R.; Wu, S.; Yu, H.; Liu, X.; Zhao, X.; Liu, S.; et al. Stool DNA Test of Methylated Syndecan-2 for the Early Detection of Colorectal Neoplasia. Cancer Epidemiol. Prev. Biomark. 2017, 26, 1411-1419. [CrossRef] [PubMed]

34. Oh, T.J.; Oh, H.I.; Seo, Y.Y.; Jeong, D.; Kim, C.; Kang, H.W.; Han, Y.D.; Chung, H.C.; Kim, N.K.; An, S. Feasibility of quantifying SDC2 methylation in stool DNA for early detection of colorectal cancer. Clin. Epigenet. 2017, 9, 126. [CrossRef] [PubMed]

35. Park, Y.S.; Kim, D.S.; Cho, S.W.; Park, J.W.; Jeon, S.J.; Moon, T.J.; Kim, S.H.; Son, B.K.; Oh, T.J.; An, S.; et al. Analysis of Syndecan-2 Methylation in Bowel Lavage Fluid for the Detection of Colorectal Neoplasm. Gut Liver 2018, 12, 508-515. [CrossRef] [PubMed]

36. Han, Y.D.; Oh, T.J.; Chung, T.H.; Jang, H.W.; Kim, Y.N.; An, S.; Kim, N.K. Early detection of colorectal cancer based on presence of methylated syndecan-2 (SDC2) in stool DNA. Clin. Epigenet. 2019, 11, 51. [CrossRef]

37. Wang, J.; Liu, S.; Wang, H.; Zheng, L.; Zhou, C.; Li, G.; Huang, R.; Wang, H.; Li, C.; Fan, X.; et al. Robust performance of a novel stool DNA test of methylated SDC2 for colorectal cancer detection: A multicenter clinical study. Clin. Epigenet. 2020, 12, 162. [CrossRef]

38. Su, W.C.; Kao, W.Y.; Chang, T.K.; Tsai, H.L.; Huang, C.W.; Chen, Y.C.; Li, C.C.; Hsieh, Y.C.; Yeh, H.J.; Chang, C.C.; et al. Stool DNA test targeting methylated syndecan-2 (SDC2) as a noninvasive screening method for colorectal cancer. Biosci. Rep. 2021, 41, BSR20201930. [CrossRef]

39. Shayan, M.; Shariatpanahi, A.M.; Seifati, S.; Kerachian, M.A. Aberrant SEPT9 methylation in plasma cell-free DNA of CRC patients. Biomed. Res. 2018, 29, 3654-3659. [CrossRef]

40. Fu, B.; Yan, P.; Zhang, S.; Lu, Y.; Pan, L.; Tang, W.; Chen, S.; Chen, S.; Zhang, A.; Liu, W. Cell-Free CirculatingMethylated SEPT9 forNoninvasive Diagnosis and Monitoring of Colorectal Cancer. Dis. Markers 2018, 2018, 6437104. [CrossRef] [PubMed]

41. Xie, L.; Jiang, X.; Li, Q.; Sun, Z.; Quan, W.; Duan, Y.; Li, D.; Chen, T. Diagnostic Value of Methylated Septin9 for Colorectal Cancer Detection. Front. Oncol. 2018, 8, 247. [CrossRef]

42. Yang, X.; Xu, Z.J.; Chen, X.; Zeng, S.S.; Qian, L.; Wei, J.; Peng, M.; Wang, X.; Liu, W.L.; Ma, H.Y.; et al. Clinical value of preoperative methylated septin 9 in Chinese colorectal cancer patients. World J. Gastroenterol. 2019, 25, 2099-2109. [CrossRef] [PubMed]

43. Sun, J.; Fei, F.; Zhang, M.; Li, Y.; Zhang, X.; Zhu, S.; Zhang, S. The role of mSEPT9 in screening, diagnosis, and recurrence monitoring of colorectal cancer. BMC Cancer 2019, 19, 450. [CrossRef] [PubMed]

44. Ma, Z.Y.; Law, W.L.; Ng, E.K.O.; Chan, C.S.Y.; Lau, K.S.; Cheng, Y.Y.; Shin, V.Y.; Kwong, A.; Leung, W.K. Methylated Septin 9 and Carcinoembryonic Antigen for Serological Diagnosis and Monitoring of Patients with Colorectal Cancer After Surgery. Sci. Rep. 2019, 9, 10326. [CrossRef] [PubMed]

45. .Liu, Y.; Zhao, G.; Miao, J.; Li, H.; Ma, Y.; Liu, X.; Li, S.; Zhu, Y.; Xiong, S.; Zheng, M.; et al. Performance Comparison Between Plasma and Stool Methylated SEPT9 Tests for Detecting Colorectal Cancer. Front. Genet. 2020, 11, 324. [CrossRef] [PubMed]

46. Houshmand, M.; Abbaszadegan, M.R.; Kerachian, M.A. Assessment of Bone Morphogenetic Protein 3 Methylation in Iranian Patients with Colorectal Cancer. Middle East J. Dig. Dis. 2017, 9, 158-163. [CrossRef] [PubMed]

47. Ashoori, H.; Ghamarchehreh, M.E.; Tavallaei, M.; Ganji, S.M.; Hosseini, M.; Zolfaghari, M.; Ghamarchehreh, Z.; Vahidian, F. Evaluation of the epigenetic biomarker bone morphogenic protein 3 for colorectal cancer diagnosis. J. Clin. Diagn. Res. 2018, 12, GC07-GC09. [CrossRef] 
48. Chen, Y.; Wang, Z.; Zhao, G.; Sun, C.; Ma, Y.; Zhang, L.; Zheng, M.; Li, H. Performance of a Novel Blood-Based Early Colorectal Cancer Screening Assay in Remaining Serum after the Blood Biochemical Test. Dis. Markers 2019, 2019, 5232780. [CrossRef] [PubMed]

49. Zhao, G.; Li, H.; Yang, Z.; Wang, Z.; Xu, M.; Xiong, S.; Li, S.; Wu, X.; Liu, X.; Wang, Z.; et al. Multiplex methylated DNA testing in plasma with high sensitivity and specificity for colorectal cancer screening. Cancer Med. 2019, 8, 5619-5628. [CrossRef] [PubMed]

50. Zhao, G.; Liu, X.; Liu, Y.; Li, H.; Ma, Y.; Li, S.; Zhu, Y.; Miao, J.; Xiong, S.; Fei, S.; et al. Aberrant DNA Methylation of SEPT9 and SDC2 in Stool Specimens as an Integrated Biomarker for Colorectal Cancer Early Detection. Front. Genet. 2020, 11, 643. [CrossRef]

51. Zhang, G.; He, F.; Zhao, G.; Huang, Z.; Li, X.; Xia, X.; Guo, Y.; Xu, W.; Xiong, S.; Ma, Y.; et al. Combining Serum DNA Methylation Biomarkers and Protein Tumor Markers Improved Clinical Sensitivity for Early Detection of Colorectal Cancer. Int. J. Genom. 2021, 2021, 6613987. [CrossRef]

52. Chen, Z.; Zhao, G.; Wang, K.; Wang, X.; Ma, Y.; Xiong, S.; Zheng, M.; Fei, S. Blood leukocytes methylation levels analysis indicate methylated plasma test is a promising tool for colorectal cancer early detection. J. Cancer 2021, 12, 3678-3685. [CrossRef]

53. Oh, T.; Kim, N.; Moon, Y.; Kim, M.S.; Hoehn, B.D.; Park, C.H.; Kim, T.S.; Kim, N.K.; Chung, H.C.; An, S. Genome-wide identification and validation of a novel methylation biomarker, SDC2, for blood-based detection of colorectal cancer. J. Mol. Diagn. 2013, 15, 498-507. [CrossRef] [PubMed]

54. Sun, J.; Zheng, M.Y.; Li, Y.W.; Zhang, S.W. Structure and function of Septin 9 and its role in human malignant tumors. World J. Gastrointest. Oncol. 2020, 12, 619-631. [CrossRef]

55. Shen, N.; Wang, T.; Li, D.; Zhu, Y.; Xie, H.; Lu, Y. Hypermethylation of the SEPT9 Gene Suggests Significantly Poor Prognosis in Cancer Patients: A Systematic Review and Meta-Analysis. Front. Genet. 2019, 10, 887. [CrossRef] [PubMed]

56. Kokabu, S.; Rosen, V. BMP3 expression by osteoblast lineage cells is regulated by canonical Wnt signaling. FEBS Open Bio 2018, 8 , 168-176. [CrossRef]

57. Wen, J.; Liu, X.; Qi, Y.; Niu, F.; Niu, Z.; Geng, W.; Zou, Z.; Huang, R.; Wang, J.; Zou, H. BMP3 suppresses colon tumorigenesis via ActRIIB/SMAD2-dependent and TAK1/JNK signaling pathways. J. Exp. Clin. Cancer Res. 2019, 38, 428. [CrossRef] [PubMed]

58. Vaes, N.; Lentjes, M.H.F.M.; Gijbels, M.J.; Rademakers, G.; Daenen, K.L.; Boesmans, W.; Wouters, K.A.D.; Geuzens, A.; Qu, X.; Steinbusch, H.P.J.; et al. NDRG4, an early detection marker for colorectal cancer, is specifically expressed in enteric neurons. Neurogastroenterol. Motil. 2017, 29, e13095. [CrossRef] [PubMed]

59. Vaes, N.; Schonkeren, S.L.; Rademakers, G.; Holland, A.M.; Koch, A.; Gijbels, M.J.; Keulers, T.G.; de Wit, M.; Moonen, L.; van der Meer, J.R.M.; et al. Loss of enteric neuronal Ndrg4 promotes colorectal cancer via increased release of Nid1 and Fbln2. EMBO Rep. 2021, 22, e51913. [CrossRef]

60. Godlewski, J.; Kmiec, Z. Colorectal Cancer Invasion and Atrophy of the Enteric Nervous System: Potential Feedback and Impact on Cancer Progression. Int. J. Mol. Sci. 2020, 21, 3391. [CrossRef]

61. Bosch, L.J.W.; Melotte, V.; Mongera, S.; Daenen, K.L.J.; Coupe, V.M.H.; van Turenhout, S.T.; Stoop, E.M.; de Wijkerslooth, T.R.; Mulder, C.J.J.; Rausch, C.; et al. Multitarget Stool DNA Test Performance in an Average-Risk Colorectal Cancer Screening Population. Am. J. Gastroenterol. 2019, 114, 1909-1918. [CrossRef]

62. Mo, S.; Wang, H.; Han, L.; Xiang, W.; Dai, W.; Zhao, P.; Pei, F.; Su, Z.; Ma, C.; Li, Q.; et al. Fecal Multidimensional Assay for Non-Invasive Detection of Colorectal Cancer: Fecal Immunochemical Test, Stool DNA Mutation, Methylation, and Intestinal Bacteria Analysis. Front. Oncol. 2021, 11, 643136. [CrossRef] [PubMed]

63. Yang, C.; Wu, W.; Yang, Y.; Yang, X.; Sun, J.; Zhang, W.; Liu, K.; Ying, H.; Jiang, S.; Yu, X.; et al. Multitarget stool DNA test compared with fecal occult blood test for colorectal cancer screening. Oncol. Lett. 2020, 20, 1193-1200. [CrossRef] [PubMed]

64. Zhang, W.; Yang, C.; Wang, S.; Xiang, Z.; Dou, R.; Lin, Z.; Zheng, J.; Xiong, B. SDC2 and TFPI2 Methylation in Stool Samples as an Integrated Biomarker for Early Detection of Colorectal Cancer. Cancer Manag. Res. 2021, 13, 3601-3617. [CrossRef] [PubMed]

65. Bartak, B.K.; Kalmar, A.; Peterfia, B.; Patai, A.V.; Galamb, O.; Valcz, G.; Spisak, S.; Wichmann, B.; Nagy, Z.B.; Toth, K.; et al. Colorectal adenoma and cancer detection based on altered methylation pattern of SFRP1, SFRP2, SDC2, and PRIMA1 in plasma samples. Epigenetics 2017, 12, 751-763. [CrossRef] [PubMed]

66. Zhao, G.; Liu, X.; Liu, Y.; Ma, Y.; Yang, J.; Li, H.; Xiong, S.; Fei, S.; Zheng, M.; Zhao, X. Methylated SFRP2 and SDC2 in stool specimens for Colorectal Cancer early detection: A cost-effective strategy for Chinese population. J. Cancer 2021, 12, $2665-2672$. [CrossRef] [PubMed]

67. Freitas, M.; Ferreira, F.; Carvalho, S.; Silva, F.; Lopes, P.; Antunes, L.; Salta, S.; Diniz, F.; Santos, L.L.; Videira, J.F.; et al. A novel DNA methylation panel accurately detects colorectal cancer independently of molecular pathway. J. Transl. Med. 2018, 16, 45. [CrossRef]

68. Rasmussen, S.L.; Krarup, H.B.; Sunesen, K.G.; Johansen, M.B.; Stender, M.T.; Pedersen, I.S.; Madsen, P.H.; Thorlacius-Ussing, O. Hypemethylated DNA, a circulating biomarker for colorectal cancer detection. PLoS ONE 2017, 12, e0180809. [CrossRef]

69. Li, J.; Zhou, X.; Liu, X.; Ren, J.; Wang, J.; Wang, W.; Zheng, Y.; Shi, X.; Sun, T.; Li, Z.; et al. Detection of Colorectal Cancer in Circulating Cell-Free DNA by Methylated CpG Tandem Amplification and Sequencing. Clin. Chem. 2019, 65, 916-926. [CrossRef]

70. Chen, J.; Sun, H.; Tang, W.; Zhou, L.; Xie, X.; Qu, Z.; Chen, M.; Wang, S.; Yang, T.; Dai, Y.; et al. DNA methylation biomarkers in stool for early screening of colorectal cancer. J. Cancer 2019, 10, 5264-5271. [CrossRef]

71. Wang, D.Y.; He, K.X.; Huang, Y.; Lou, Q.Q.; He, T.; Xu, X. A New Method for the Detection of Colorectal Cancer and the Precancerous Lesions: Occult Blood Testing Combination with Promoter Methylation in the Fecal Sample. J. Cancer 2021, 12, 335-342. [CrossRef] [PubMed] 
72. Cao, Y.; Zhao, G.; Cao, Y.; Chen, Z.; Liu, X.; Yuan, M.; Yang, J.; Wang, X.; Ma, Y.; Liu, Z.; et al. Feasibility of Methylated CLIP4 in Stool for Early Detection of Colorectal Cancer: A Training Study in Chinese Population. Front. Oncol. 2021, 11, 647066. [CrossRef]

73. Suehiro, Y.; Hashimoto, S.; Higaki, S.; Fujii, I.; Suzuki, C.; Hoshida, T.; Matsumoto, T.; Yamaoka, Y.; Takami, T.; Sakaida, I.; et al. Blood free-circulating DNA testing by highly sensitive methylation assay to diagnose colorectal neoplasias. Oncotarget 2018, 9 , 16974-16987. [CrossRef] [PubMed]

74. Suehiro, Y.; Hashimoto, S.; Goto, A.; Yamaoka, Y.; Yamamoto, N.; Suzuki, N.; Higaki, S.; Fujii, I.; Suzuki, C.; Matsumoto, T.; et al. Fecal DNA Testing of TWIST1 Methylation Identifies Patients With Advanced Colorectal Adenoma Missed by Fecal Immunochemical Test for Hemoglobin. Clin. Transl. Gastroenterol. 2020, 11, e00176. [CrossRef] [PubMed]

75. Suehiro, Y.; Zhang, Y.; Hashimoto, S.; Takami, T.; Higaki, S.; Shindo, Y.; Suzuki, N.; Hazama, S.; Oka, M.; Nagano, H.; et al. Highly sensitive faecal DNA testing of TWIST1 methylation in combination with faecal immunochemical test for haemoglobin is a promising marker for detection of colorectal neoplasia. Ann. Clin. Biochem. 2018, 55, 59-68. [CrossRef] [PubMed]

76. Nagai, Y.; Sunami, E.; Yamamoto, Y.; Hata, K.; Okada, S.; Murono, K.; Yasuda, K.; Otani, K.; Nishikawa, T.; Tanaka, T.; et al. LINE-1 hypomethylation status of circulating cell-free DNA in plasma as a biomarker for colorectal cancer. Oncotarget 2017, 8, 11906-11916. [CrossRef] [PubMed]

77. Shademan, M.; Zare, K.; Zahedi, M.; Mozaffari, H.M.; Hosseini, H.B.; Ghaffarzadegan, K.; Goshayeshi, L.; Dehghani, H. Promoter methylation, transcription, and retrotransposition of LINE-1 in colorectal adenomas and adenocarcinomas. Cancer Cell Int. 2020, 20, 426. [CrossRef] [PubMed]

78. Jensen, S.Ø.; Øgaard, N.; Ørntoft, M.-B.W.; Rasmussen, M.H.; Bramsen, J.B.; Kristensen, H.; Mouritzen, P.; Madsen, M.R.; Madsen, A.H.; Sunesen, K.G.; et al. Novel DNA methylation biomarkers show high sensitivity and specificity for blood-based detection of colorectal cancer-A clinical biomarker discovery and validation study. Clin. Epigenet. 2019, 11, 158. [CrossRef]

79. Zhang, Y.; Wu, Q.; Xu, L.; Wang, H.; Liu, X.; Li, S.; Hu, T.; Liu, Y.; Peng, Q.; Chen, Z.; et al. Sensitive detection of colorectal cancer in peripheral blood by a novel methylation assay. Clin. Epigenet. 2021, 13, 90. [CrossRef]

80. Cao, Y.; Zhao, G.; Yuan, M.; Liu, X.; Ma, Y.; Cao, Y.; Miao, B.; Zhao, S.; Li, D.; Xiong, S.; et al. KCNQ5 and C9orf50 Methylation in Stool DNA for Early Detection of Colorectal Cancer. Front. Oncol. 2021, 10, 621295. [CrossRef]

81. Mousavi Ardehaie, R.; Hashemzadeh, S.; Behrouz Sharif, S.; Ghojazadeh, M.; Teimoori-Toolabi, L.; Sakhinia, E. Aberrant methylated EDNRB can act as a potential diagnostic biomarker in sporadic colorectal cancer while KISS1 is controversial. Bioengineered 2017, 8, 555-564. [CrossRef]

82. Kottorou, A.E.; Antonacopoulou, A.G.; Dimitrakopoulos, F.-I.D.; Diamantopoulou, G.; Sirinian, C.; Kalofonou, M.; Theodorakopoulos, T.; Oikonomou, C.; Katsakoulis, E.C.; Koutras, A.; et al. Deregulation of methylation of transcribed-ultra conserved regions in colorectal cancer and their value for detection of adenomas and adenocarcinomas. Oncotarget 2018, 9, 21411-21428. [CrossRef]

83. Vedeld, H.M.; Nesbakken, A.; Lothe, R.A.; Lind, G.E. Re-assessing ZNF331 as a DNA methylation biomarker for colorectal cancer. Clin. Epigenet. 2018, 10, 70. [CrossRef]

84. Li, H.; Wang, Z.; Zhao, G.; Ma, Y.; Chen, Y.; Xue, Q.; Zheng, M.; Fei, S. Performance of a MethyLight assay for methylated SFRP2 DNA detection in colorectal cancer tissue and serum. Int. J. Biol. Markers 2019, 34, 54-59. [CrossRef] [PubMed]

85. Fan, J.; Li, J.; Guo, S.; Tao, C.; Zhang, H.; Wang, W.; Zhang, Y.; Zhang, D.; Ding, S.; Zeng, C. Genome-wide DNA methylation profiles of low- and high-grade adenoma reveals potential biomarkers for early detection of colorectal carcinoma. Clin. Epigenet. 2020, 12, 56. [CrossRef]

86. Wu, X.; Zhang, Y.; Hu, T.; He, X.; Zou, Y.; Deng, Q.; Ke, J.; Lian, L.; He, X.; Zhao, D.; et al. A novel cell-free DNA methylation-based model improves the early detection of colorectal cancer. Mol. Oncol. 2021. [CrossRef] [PubMed]

87. Sui, J.; Wu, X.; Wang, C.; Wang, G.; Li, C.; Zhao, J.; Zhang, Y.; Xiang, J.; Xu, Y.; Nian, W.; et al. Discovery and validation of methylation signatures in blood-based circulating tumor cell-free DNA in early detection of colorectal carcinoma: A case-control study. Clin. Epigenet. 2021, 13, 26. [CrossRef]

88. Xiao, Z.; Wu, W.; Wu, C.; Li, M.; Sun, F.; Zheng, L.; Liu, G.; Li, X.; Yun, Z.; Tang, J.; et al. 5-Hydroxymethylcytosine signature in circulating cell-free DNA as a potential diagnostic factor for early-stage colorectal cancer and precancerous adenoma. Mol. Oncol. 2021, 15, 138-150. [CrossRef]

89. Rademakers, G.; Massen, M.; Koch, A.; Draht, M.X.; Buekers, N.; Wouters, K.A.D.; Vaes, N.; De Meyer, T.; Carvalho, B.; Meijer, G.A.; et al. Identification of DNA methylation markers for early detection of CRC indicates a role for nervous system-related genes in CRC. Clin. Epigenet. 2021, 13, 80. [CrossRef] [PubMed]

90. Vega-Benedetti, A.F.; Loi, E.; Moi, L.; Orru, S.; Ziranu, P.; Pretta, A.; Lai, E.; Puzzoni, M.; Ciccone, L.; Casadei-Gardini, A.; et al. Colorectal Cancer Early Detection in Stool Samples Tracing CpG Islands Methylation Alterations Affecting Gene Expression. Int. J. Mol. Sci. 2020, 21, 4494. [CrossRef] [PubMed]

91. Jaberie, H.; Hosseini, S.V.; Naghibalhossaini, F. Evaluation of Alpha 1-Antitrypsin for the Early Diagnosis of Colorectal Cancer. Pathol. Oncol. Res. 2020, 26, 1165-1173. [CrossRef]

92. Liu, J.; Ding, Z.; Li, G.; Tang, L.; Xu, Y.; Luo, H.; Yi, J.; Lu, Y.; Mao, R.; Nan, Q.; et al. Identification and validation of colorectal neoplasia-specific methylation biomarkers based on CTCF-binding sites. Oncotarget 2017, 8, 114183-114194. [CrossRef] [PubMed]

93. Gu, S.; Lin, S.; Ye, D.; Qian, S.; Jiang, D.; Zhang, X.; Li, Q.; Yang, J.; Ying, X.; Li, Z.; et al. Genome-wide methylation profiling identified novel differentially hypermethylated biomarker MPPED2 in colorectal cancer. Clin. Epigenet. 2019, 11, 41. [CrossRef] [PubMed] 
94. Liu, Y.; Wei, E.; Zhao, J.; Kong, D.; Li, B. Downregulation of SM22 $\alpha$ protein by hypermethylation of its promoter in colorectal cancer. Oncol. Lett. 2018, 15, 7675-7680. [CrossRef] [PubMed]

95. Chang, S.C.; Liew, P.L.; Ansar, M.; Lin, S.Y.; Wang, S.C.; Hung, C.S.; Chen, J.Y.; Jain, S.; Lin, R.K. Hypermethylation and decreased expression of TMEM240 are potential early-onset biomarkers for colorectal cancer detection, poor prognosis, and early recurrence prediction. Clin. Epigenet. 2020, 12, 67. [CrossRef] [PubMed]

96. Bailey, C.S.; Moldenhauer, H.J.; Park, S.M.; Keros, S.; Meredith, A.L. KCNMA1-linked channelopathy. J. Gen. Physiol. 2019, 151, 1173-1189. [CrossRef]

97. Basile, M.S.; Fagone, P.; Mangano, K.; Mammana, S.; Magro, G.; Salvatorelli, L.; Li Destri, G.; La Greca, G.; Nicoletti, F.; Puleo, S.; et al. KCNMA1 Expression is Downregulated in Colorectal Cancer via Epigenetic Mechanisms. Cancers 2019, 11, 245. [CrossRef]

98. Ponomaryova, A.A.; Rykova, E.Y.; Azhikina, T.L.; Bondar, A.A.; Cheremisina, O.V.; Rodionov, E.O.; Boyarko, V.V.; Laktionov, P.P.; Cherdyntseva, N.V. Long interspersed nuclear element-1 methylation status in the circulating DNA from blood of patients with malignant and chronic inflammatory lung diseases. Eur. J. Cancer Prev. 2021, 30, 127-131. [CrossRef]

99. Xia, T.; Sun, H.; Huang, H.; Bi, H.; Pu, R.; Zhang, L.; Zhang, Y.; Liu, Y.; Xu, J.; Onwuka, J.U.; et al. Androgen receptor gene methylation related to colorectal cancer risk. Endocr. Connect. 2019, 8, 979-987. [CrossRef]

100. Ashktorab, H.; Rahi, H.; Nouraie, M.; Shokrani, B.; Lee, E.; Haydari, T.; Laiyemo, A.O.; Siegel, P.; Brim, H. GPNMB methylation: A new marker of potentially carcinogenic colon lesions. BMC Cancer 2018, 18, 1068. [CrossRef]

101. Li, D.; Bai, Y.; Feng, Z.; Li, W.; Yang, C.; Guo, Y.; Lin, C.; Zhang, Y.; He, Q.; Hu, G.; et al. Study of Promoter Methylation Patterns of HOXA2, HOXA5, and HOXA6 and Its Clinicopathological Characteristics in Colorectal Cancer. Front. Oncol. 2019, 9, 394. [CrossRef]

102. Fadda, A.; Gentilini, D.; Moi, L.; Barault, L.; Leoni, V.P.; Sulas, P.; Zorcolo, L.; Restivo, A.; Cabras, F.; Fortunato, F.; et al. Colorectal cancer early methylation alterations affect the crosstalk between cell and surrounding environment, tracing a biomarker signature specific for this tumor. Int. J. Cancer 2018, 143, 907-920. [CrossRef]

103. Kerachian, M.A.; Javadmanesh, A.; Azghandi, M.; Shariatpanahi, A.M.; Yassi, M.; Shams Davodly, E.; Talebi, A.; Khadangi, F.; Soltani, G.; Hayatbakhsh, A.; et al. Crosstalk between DNA methylation and gene expression in colorectal cancer, a potential plasma biomarker for tracing this tumor. Sci. Rep. 2020, 10, 2813. [CrossRef]

104. Heiss, J.A.; Brenner, H. Epigenome-wide discovery and evaluation of leukocyte DNA methylation markers for the detection of colorectal cancer in a screening setting. Clin. Epigenet. 2017, 9, 24. [CrossRef]

105. Wang, X.; Wang, D.; Zhang, H.; Feng, M.; Wu, X. Genome-wide analysis of DNA methylation identifies two CpG sites for the early screening of colorectal cancer. Epigenomics 2020, 12, 37-52. [CrossRef]

106. Uhan, S.; Zidar, N.; Tomažič, A.; Hauptman, N. Hypermethylated promoters of genes UNC5D and KCNA1 as potential novel diagnostic biomarkers in colorectal cancer. Epigenomics 2020, 12, 1677-1688. [CrossRef] [PubMed]

107. Li, D.J.; Feng, Z.C.; Li, X.R.; Hu, G. Involvement of methylation-associated silencing of formin 2 in colorectal carcinogenesis. World J. Gastroenterol. 2018, 24, 5013-5024. [CrossRef] [PubMed]

108. Zhou, D.; Tang, W.; Zhang, Y.; An, H.X. JAM3 functions as a novel tumor suppressor and is inactivated by DNA methylation in colorectal cancer. Cancer Manag. Res. 2019, 11, 2457-2470. [CrossRef] [PubMed]

109. Ibrahim, J.; Op de Beeck, K.; Fransen, E.; Croes, L.; Beyens, M.; Suls, A.; Vanden Berghe, W.; Peeters, M.; Van Camp, G. Methylation analysis of Gasdermin E shows great promise as a biomarker for colorectal cancer. Cancer Med. 2019, 8, 2133-2145. [CrossRef] [PubMed]

110. Panagopoulou, M.; Cheretaki, A.; Karaglani, M.; Balgkouranidou, I.; Biziota, E.; Amarantidis, K.; Xenidis, N.; Kakolyris, S.; Baritaki, S.; Chatzaki, E. Methylation Status of Corticotropin-Releasing Factor (CRF) Receptor Genes in Colorectal Cancer. J. Clin. Med. 2021, 10, 2680. [CrossRef]

111. Ansar, M.; Wang, C.J.; Wang, Y.H.; Shen, T.H.; Hung, C.S.; Chang, S.C.; Lin, R.K. SMAD3 Hypomethylation as a Biomarker for Early Prediction of Colorectal Cancer. Int. J. Mol. Sci. 2020, 21, 7395. [CrossRef] [PubMed]

112. Li, D.; Zhang, L.; Fu, J.; Huang, H.; Sun, S.; Zhang, D.; Zhao, L.; Ucheojor Onwuka, J.; Zhao, Y.; Cui, B. SCTR hypermethylation is a diagnostic biomarker in colorectal cancer. Cancer Sci. 2020, 111, 4558-4566. [CrossRef]

113. Zhang, T.; Cui, G.; Yao, Y.L.; Wang, Q.C.; Gu, H.G.; Li, X.N.; Zhang, H.; Feng, W.M.; Shi, Q.L.; Cui, W. Value of CNRIP1 promoter methylation in colorectal cancer screening and prognosis assessment and its influence on the activity of cancer cells. Arch. Med. Sci. 2017, 13, 1281-1294. [CrossRef]

114. Otero-Estevez, O.; Gallardo-Gomez, M.; Cadena, M.P.; Rodriguez-Berrocal, F.J.; Cubiella, J.; Ramirez, V.H.; Garcia-Nimo, L.; Chiara, L. Value of Serum NEUROG1 Methylation for the Detection of Advanced Adenomas and Colorectal Cancer. Diagnostics 2020, 10, 437. [CrossRef]

115. Ye, X.; Mo, M.; Xu, S.; Yang, Q.; Wu, M.; Zhang, J.; Chen, B.; Li, J.; Zhong, Y.; Huang, Q.; et al. The hypermethylation of p16 gene exon 1 and exon 2: Potential biomarkers for colorectal cancer and are associated with cancer pathological staging. BMC Cancer 2018, 18, 1023. [CrossRef] [PubMed]

116. De'angelis, G.L.; Bottarelli, L.; Azzoni, C.; De'angelis, N.; Leandro, G.; Di Mario, F.; Gaiani, F.; Negri, F. Microsatellite instability in colorectal cancer. Acta Biomed. 2018, 89, 97-101. [CrossRef]

117. Malki, A.; Elruz, R.A.; Gupta, I.; Allouch, A.; Vranic, S.; Al Moustafa, A.E. Molecular mechanisms of colon cancer progression and metastasis: Recent insights and advancements. Int. J. Mol. Sci. 2021, 22, 130. [CrossRef] [PubMed] 
118. Morán, A. Differential colorectal carcinogenesis: Molecular basis and clinical relevance. World J. Gastrointest. Oncol. 2010, 2, 151. [CrossRef] [PubMed]

119. Keller, L.; Belloum, Y.; Wikman, H.; Pantel, K. Clinical relevance of blood-based ctDNA analysis: Mutation detection and beyond. Br. J. Cancer 2021, 124, 345-358. [CrossRef]

120. Song, L.; Li, Y.; Jia, J.; Zhou, G.; Wang, J.; Kang, Q.; Jin, P.; Sheng, J.; Cai, G.; Cai, S.; et al. Algorithm Optimization in Methylation Detection with Multiple RT-qPCR. PLoS ONE 2016, 11, e0163333. [CrossRef] 